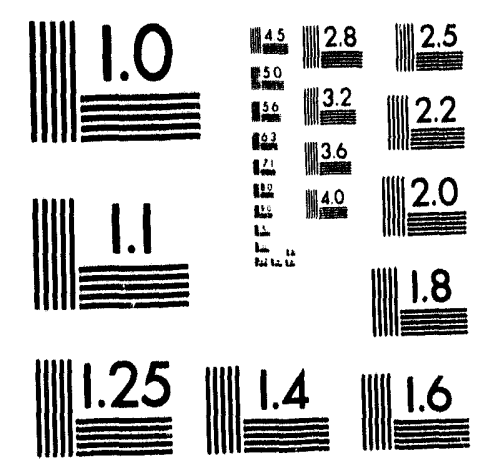




\title{
DOE/CE/15533-T6
}

\section{HIGH EFFICIENCY SHALE OIL RECOVERY}

\author{
FINAL REPORT
}

Invention \#533

Contract \# DE-FG01-92CE15533

For Period January 1, 1992 to June 30, 1993

Submitted to

The U. S. Dept. of Energy

Office of Energy Related Inventions

By

D. Carlos Adams, $\mathrm{PhD}$

De urbe Alunc Date: Sept. 29, 1993 Principle Investigator and Company Owner

ENERGY RECOVERY TECHNOLOGY

886 Monument Park Circle

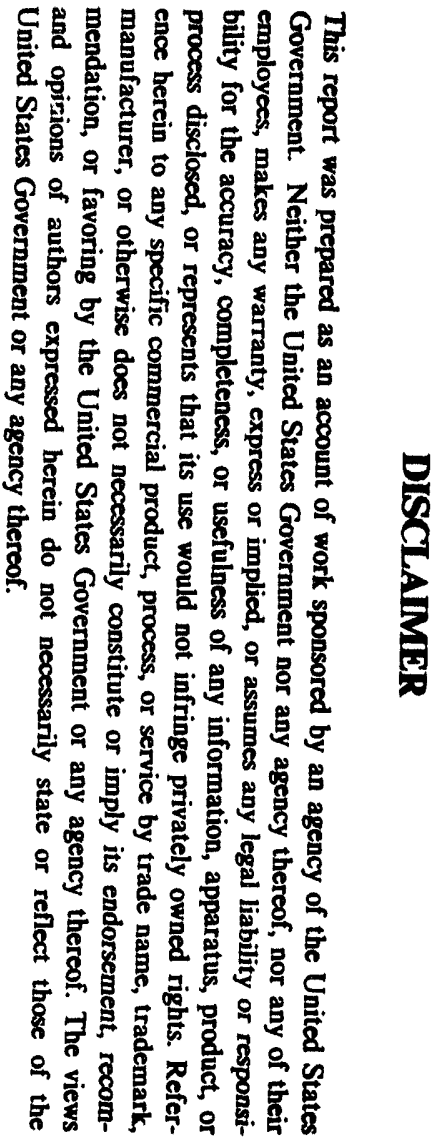

Salt Lake City, Utah 84108

Phone: 801/583-6744 


\section{PROJECT SUMMARY}

The Adams Counter-current shale oil recovery process is an improved retorting technology enabling highly efficient oil recovery from oil shale. The high efficiency results primarily from the following facts: it (1) recovers the ash heat to preheat the feed ore, (2) burns and uses the coke energy and (3) operates without using hot ash recycling as a heat carrier. This latter feature is doubly important, contributing to high oil yield and to the generation of highly reactive coke which can be burned below $1000^{\circ} \mathrm{F}$, avoiding the endothermal calcination of the mineral carbonates and helping to clean the ash of contaminants. This project demonstrates that oil shale can be retorted under the specified conditions and achieve the objectives of very high efficiency.

The project accomplished the following: (1) 51 quartz sand rotary kiln runs provided significant engineering data. A heat transfer value of $107 \mathrm{Btu} / \mathrm{hr} / \mathrm{ft}^{2} /{ }^{\circ} \mathrm{F}$ was obtained at optimum RPM. The data are compared with the literature. (2) Eight oil shale samples were obtained and preliminary shakedown runs were made. Five of the samples, those with prior analytical data, were selected for kiln processing and twelve pyrolysis runs were made on the five different oil shales. All of the runs exhibited a complete absence of any surfaceadhering solids or particle agglomeration. The average heat transfer in the rotary kiln was $78 \mathrm{Btu} / \mathrm{hr} / \mathrm{ft}^{2} /{ }^{\circ} \mathrm{F}$ for Green River oil shale, which will provide adequate heat exchange for the success of the Adams kiln. (3) Average oil recovery was $109 \%$ of Fisher Assay. (4) Retorted residue from all five samples was oxidized at approximately $1000^{\circ} \mathrm{F}$. The ash from these runs was oxidized to varying extents, depending on the oil shale type and oxidizing temperatures. While $1000^{\circ} \mathrm{F}$ is adequately hot to provide process heat from coke combustion for these ores, some Eastern oil shales, without mineral carbonates, may be oxidized at higher temperatures, perhaps 100-300 degrees hotter, to obtain a more complete oxidation and utilization of the coke.

\section{INTRODUCTION}

Background: The Counter-current Heat Exchange between Solid Streams or CHESS ${ }^{1}$ oil recovery process was the subject of two SBIR Phase I projects prior to the current project. In 1987 the small batch rotary kiln was constructed and the project demonstrated fairly efficient recovery of tar sand bitumen. In a 1990 project, an important feature of the CHESS retort, the gas lock, was demonstrated, showing that the lock could effectively conduct granular solids from the pyrolyzer to the combustor while disallowing passage of either the pyrolysis or the combustion gases. ${ }^{2}$

The CHESS process is an inexpensive, high efficiency oil and heat recovery kiln for retorting oil shale and other fossil bitumens with minimal environmental impact. It consists of a rotary kiln with an inner concentric high surface area cylinder. The cold ore feeds into the inner cylinder and heats as it passes the hot burning ash, moving in the opposite direction in the annular space of the outer cylinder. Thus it achieves high heat recovery without mixing the solid streams. ${ }^{3}$

Project Objective: The overall project objective is to demonstrate the high efficiency of the Adams CHESS process. The efficiency is first being demonstrated on a small scale, in the current phase, after which the demonstration will be extended to the operation of a small pilot plant. Thus the immediate project objective is to obtain data on oil shale retorting 
operations in a small batch rotary kiln that is representative of operations in the proposed continuous process pilot plant. Although an oil shale batch sample is sealed in the batch kiln from the start until the end of the run, the process conditions for the batch are the same as the conditions that an element of oil shale would encounter in a continuous process kiln. Similar chemical and physical conditions (heating, mixing, pyrolysis, oxidation) exist in both systems.

Important data objectives for this phase of the project were demonstrated: (1) that the heat recovery forecast for this project is reasonable, (2) that the Adams concept oil shale kiln would run continuously and not plug up from particle agglomeration and adhesion to inner kiln surfaces, (3) that oil shale coke could be burned at temperatures as low as $1000^{\circ} \mathrm{F}$ (for the carbonate-containing Green River oil shale) to provide adequate process heat, even from lean ore. Other objectives were also demonstrated: (4) that the oil recovery would be substantially higher than recycled ash processes, which are typically below $90 \%$ of Fisher Assay, and (5) that low heat and temperature requirements equate to a minimal environmental impact.

Heat transfer for this project is high by standards of conventional rotary kilns. The reason is because (1) the heat transfer is not from a hot gas to the solids but from solids to solids, and (2) there is relatively high surface velocity between the wall and the solids. Heat transfer in the CHESS kiln should be compared, not to conventional kilns (of about 10 $\mathrm{Btu} / \mathrm{hr} / \mathrm{ft}^{2} /{ }^{\circ} \mathrm{F}$ ), but to fluidized bed systems (about $100 \mathrm{Btu} / \mathrm{hr} / \mathrm{ft}^{\circ}{ }^{\circ} \mathrm{F}$ ). Desai compared experiments with flowing granular media beds with fluidized beds and showed that heai transfer was generally higher for the flowing beds than for fluidized beds. ${ }^{4}$

\section{EXPERIMENTAL}

\section{Equipment Description}

Kiln: The batch kiln used in this project is a modification of the unit constructed in 1987. A description of the kiln is given in Figs. 1, 2 and 3, which show cross sections of the main features of the kiln. Fig. 1 is a cross section of the overall furnace and kiln assembly. Dimensions of the kiln are given in Fig. 2 and details of the reactor section are shown in Fig. 3. The rotational velocity (RPM) was controlled by a variable speed motor (not shown). Kiln RPM ranged from $0-200$ RPM or a surface velocity of $0-280 \mathrm{ft} / \mathrm{min}$. (The surface we are concerned with is the internal kiln wall where the granular particles slide and are heated or cooled as the kiln rotates. The kiln has an ID of 5.4", an internal circumference of $1.41 \mathrm{ft}$, so the surface velocity in $\mathrm{ft} /$ minute is just $1.41 \mathrm{X} \mathrm{RPM}$ ).

Furnace and Temperature Control: The kiln furnace was designed originally with three heaters (see Fig. 3, HTR \#1, $\# 2$ and $\# 3$ ) to provide a flat temperature profile (which was partially successful). However, temperature uniformity was greatly improved in this project with the addition of heaters $\# 4$ and $\# 5$ on the kiln ends. The temperature heat-up was controlled by a system installed for this project in an IBM compatible 286 process-automation computer. The computer interface to the kiln consisted of DAS-08, MUX-32 and CTR-05 boards from ComputerBoards Inc. Eighteen thermocouples were used. The output from 16 of these were fed into the MUX-32 multiplexer and then to the CIO-AD08 analog-to-digital converter board. The CTR- 05 controlled the 240 volt, five-zone power and temperature control by means of time-proportioning output through five pairs (driver plus power controller) of solid state relays. 


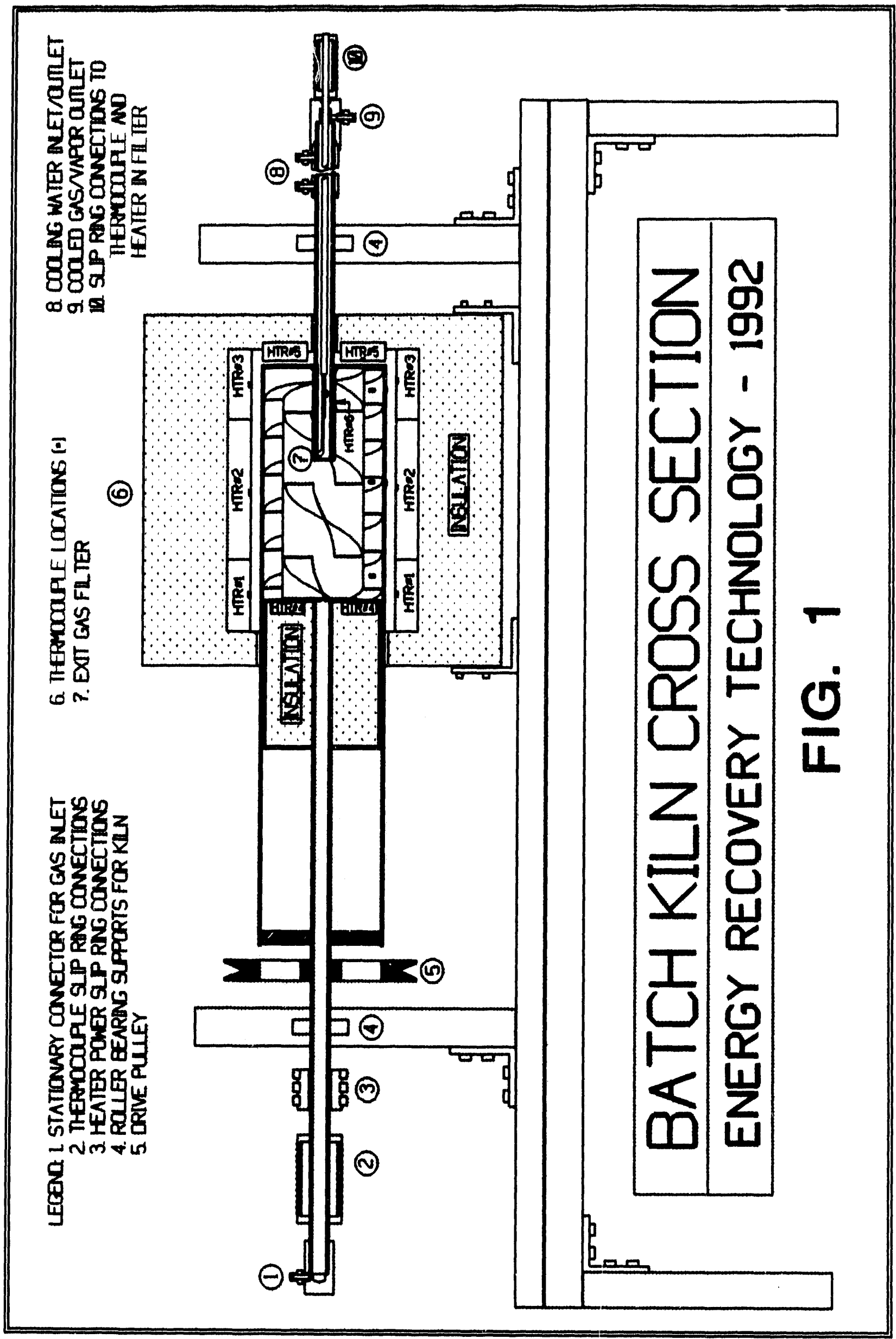




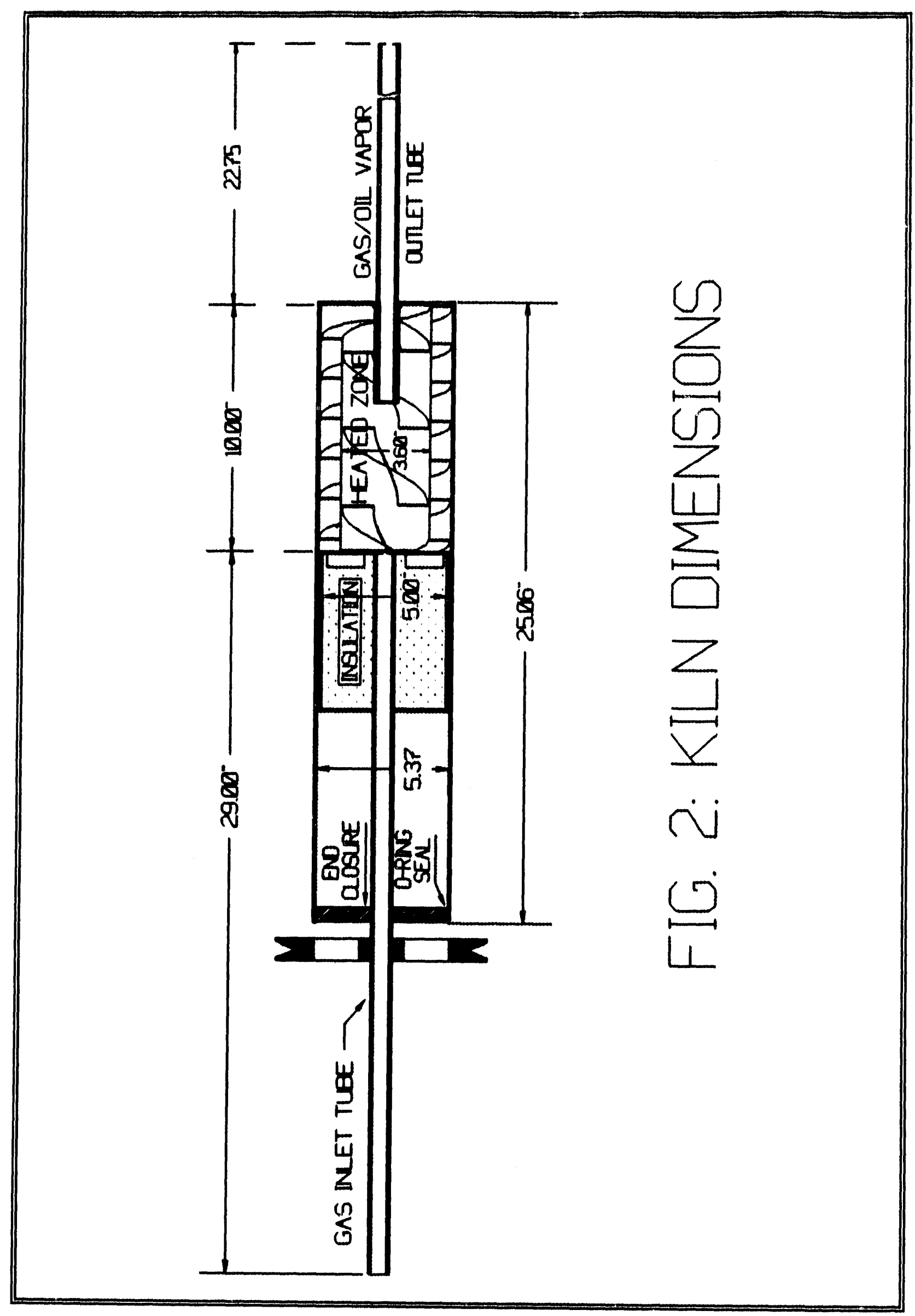




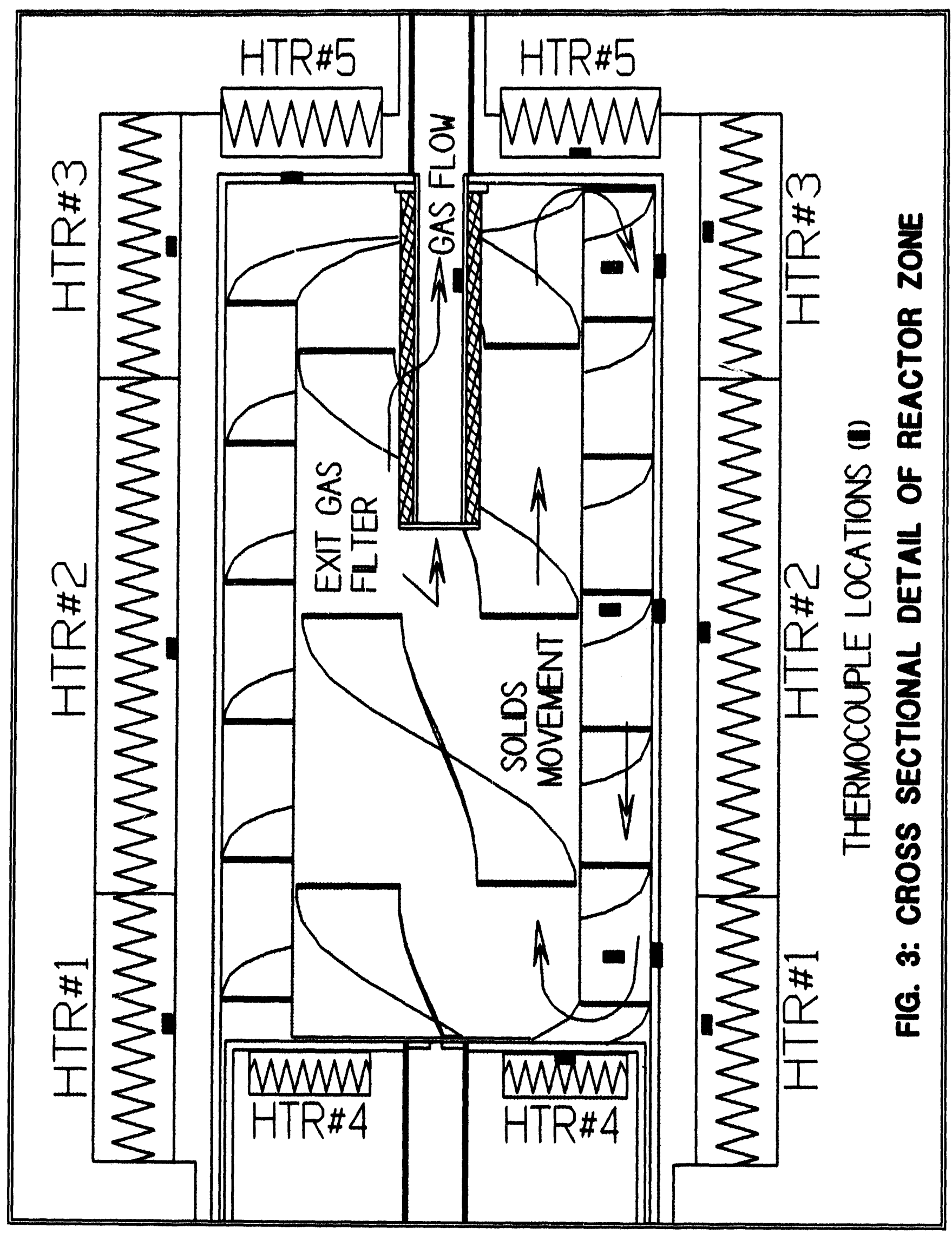


Computer Program: Time proportioned temperature control was provided by means of our own software "Kilntrol" program. Kilntrol provided for complete PID control (Proportioning, Integral and Derivative parameter control) and allowed for the desired versatility and alterations as they were needed.

\section{Sample Preparation}

Quartz Sand: When a material of known heat capacity is heated in the rotary kiln, the Heat Transfer Coefficient (U) between the kiln and the material can be measured. Commercial quartz sand (30 and 70 mesh) was used as a standard granular material of known heat capacity to obtain the basic Heat Transfer characteristics of the kiln.

Qil Shale: Eight primary oil shale samples were collected from institutions as follows: Four samples from Western Research Institute (WRI), Laramie, WY; one sample from Lawrence Livermore National Laboratory (LLNL), Livermore, CA; and three samples from the University of Utah (U of U), Salt Lake City, UT. Typical values of Fisher Assay were included with the five samples from WRI and LLNL. Consequently, these five samples were chosen for project processing. The LLNL sample is referred to as Occidental and the WRI samples as Parachute, Tipton, Kentucky and Indiana. All are Green River samples except the latter two which are Eastern oil shales. These and one $U$ of $U$ sample were crushed to -7 mesh (i.e. passing through 7 mesh sieve). These primary samples $(20 \mathrm{~kg}$ each) were then riffle-divided into secondary sample batches (1 $\mathrm{kg}$ each), and then sealed in an atmosphere of $\mathrm{CO}_{2}$ to minimize any oxidation of the fine particles in case there should be any significant delay in the time of processing the different samples. Data that accompanied the WRI and LLNL samples are included in Appendix E. The values are approximate to our samples, as can be seen by the wide spread in some of the data.

\section{Assembly and Operation}

Kiln: The furnace is formed of top and bottom halves, with the two halves hinged together in the back. The top is lifted and rotated toward the back side of the stand for access to the kiln. The end closure, inlet tube, drive pulley, "insulator can" (in the kiln center with \#4 heater), the auger blades and internal thermocouples are all inserted and removed as a single assembly unit when closing and opening the kiln. Thus sand or oil shale was loaded into the cylindrical kiln, with the gas filter, item 7, already in place. (Item numbers refer to numbers in Fig.1.) Then the end closure with auger blades etc. is assembled with the closure O-ring sealing the solids inside. The kiln is next placed in the furnace/stand cradle where the three slip rings (items 2,3 and 10) mate with the slip ring brushes attached to the stand (brushes not shown), and all the electrical and instrumental connections to the rotary kiln are then complete. A pulley belt in position over the motor and drive pulleys (item 5) is taut as the assembly is tightened into place by means of two clamps, one over each roller bearing (items 4). After making the gas line and water connections, the run is ready to begin.

Sand Runs: Quartz sand is essentially inert for our application, below $1000^{\circ} \mathrm{F}$. Nevertheless, nitrogen sweep gas flow was used with the sand runs to simulate the conditions of oil shale runs. Gas entered the kiln at room temperature and exited at kiln temperature. Cooling water was used in the Exit Tube condenser to protect the O-ring seals on the rotary outlet seal. Thereafter the gas was vented directly without other treatment.

Qil Shale Runs: Nitrogen sweep-gas flowed through the kiln at 14 liters/min (space 
velocity of $3.76 / \mathrm{min}$ ). Offgas from the oil shale runs required significant treatment. The flow diagram in Fig. 4 shows the sequence of cooling, condensing, filtering and precipitation on $\mathrm{NaOH}$ pellets (to collect gas contaminants, principally $\mathrm{H}_{2} \mathrm{~S}$ and $\mathrm{CO}_{2}$ gases). Thereafter the gas was evacuated by vacuum pump and discarded.

\section{Mensuration: Weight} measurements were taken on one of two balances: a 200 gram capacity, 0.1 milligram sensitivity; and a 1 kilogram capacity, 0.01 gram sensitivity units. In one run (Indiana \#2) the center auger blade was inadvertently omitted from the run. This slowed the heating rate and heat conductance, however, the product yield was fairly good for the run. Oil density was determined with a $10 \mathrm{cc}$ pycnometer. Oil pour point was determined to the nearest $5^{\circ} \mathrm{F}$. Alkalinity or $\mathrm{pH}$ was measured with Micro Essential Labs pHydrion paper measuring in the $\mathrm{pH}$ range of 1 to 11 . Sieving measurements were obtained in an 8" sieving set and 30 minute shake period. Sieve sizes are shown in Appendix D.

\section{Sample Analysis}

Analysts: Chemical analyses and Fischer Assay were performed by Western Research Institute (WRI). All samples were submitted to WRI together, to optimize the sample analysis uniformity. Rock density and Thermogravimetric analyses (TGA) were performed at the University of Utah Experimental Survey. Weight, volume, density, pour point, pH and sieving measurements on the feed for the runs and the products from the runs were made with Energy Recovery Tech. equipment and personnel. All the analytical and weight data on samples and runs are summarized in Appendices A, B and C. TGA data were used as a guide, primarily in the oxidation runs and are included as Appendix $G$.

Raw Oil Shale: One secondary $(1 \mathrm{Kg})$ sample from each primary $(20 \mathrm{~kg})$ sample of raw oil shale was riffle-divided into 500 gram samples, one to be analyzed for Fisher Assay. Approximately 100 grams were riffle-divided from the rest of each secondary sample. The 100 gram sample was ground to -20 mesh and a 10 gram sample divided out. The 10 gram sample was further ground to -100 mesh. $^{5}$ Finally, samples ( 2 grams each) of the -100 mesh ore were submitted for Total Carbon, Hydrogen and Nitrogen (CHN) and Mineral Carbon analyses. Our main interest was in the Organic Carbon, (i.e. the difference between the Total Carbon and Mineral Carbon) and the Fisher Assay. The sum of Organic Carbon plus Hydrogen plus Nitrogen can provide a low estimate of the organic matter in a sample. The estimate would be low because it would not include organic sulfur and oxygen. ${ }^{6}$

Retorted Oil Shale and Ash: Samples were prepared by grinding and subdividing as was described above. Samples of 2 grams from one or more oil shale runs and one ash sample from each of the five oil shale samples were submitted to WRI for analysis. 


\section{RESULTS AND DISCUSSION}

Heat Transfer--Sand Runs: In the batch rotary kiln, heat is transferred from the furnace to the kiln wall and from the wall to the inner contents of the kiln. The temperatures for a typical run wherein the furnace was programmed to heat immediately to the maximum temperature is plotted in Fig. 5. It can be observed from this figure how the heating rate (slope) of kiln wall temperature vs time, is proportional to the temperature difference between the wall and the furnace. Note that at about 6 minutes, where the furnace temperature levels off, the point of maximum temperature difference between the wall and the furnace is also the point of steepest slope for the kiln heating rate. Similarly, the heating rate of the inner kiln contents is proportional to the temperature difference between the kiln wall and the inner kiln contents.

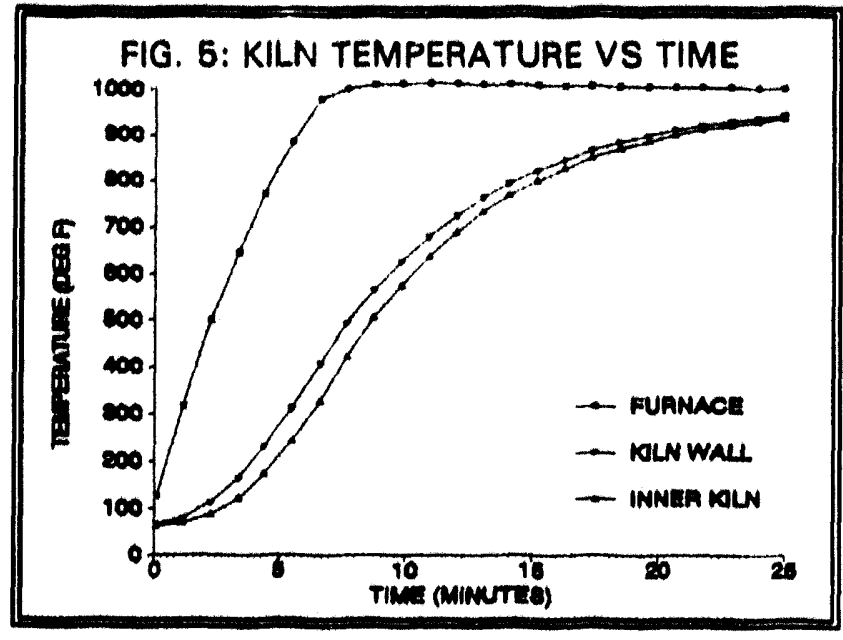

Mathematical Model: An Unsteady State Heat Analysis of the rotary kiln allows us to obtain the Coefficient of Heat Transfer for the system: During the time moment, dt, the sand heats $\mathrm{dT}_{\mathrm{s}}$. Some of the heat transfers from the sand to the inner kiln (auger blade assembly) and the inner assembly heats $\mathrm{dT}_{\mathrm{A}}$. Assuming that the internal kiln temperature increment, $\mathrm{dT}_{\mathrm{A}}$, will be proportional to $\mathrm{dT}_{\mathrm{s}}$, then $\mathrm{dT}_{\mathrm{A}}=\mathrm{kdT}$. The increase in sand energy in time moment, dt, is given by:

Change in Sand Energy = Heat Flow to Sand - Heat Flow to Inner auger

Thus:

$$
\mathrm{m}_{\mathrm{s}} \mathrm{c}_{\mathrm{s}} \mathrm{dT}_{\mathrm{s}}=\mathrm{UA} \mathrm{F}_{\mathrm{c}} \Delta \mathrm{T} \mathrm{dt}-\mathrm{m}_{\mathrm{A}} \mathrm{c}_{\mathrm{A}} \mathrm{k} d \mathrm{~T}_{\mathrm{s}}
$$

Where $\mathrm{T}=$ Temp. $\left({ }^{\circ} \mathrm{F}\right)$

$\Delta \mathrm{T}=$ Delta $\mathrm{T}=$ Wall Temp. - Sand Temp.

$\mathrm{U}=$ Thermal Conductance from the kiln wall to the sand $\left(\mathrm{Btu} / \mathrm{hr} / \mathrm{ft}^{2} /{ }^{\circ} \mathrm{F}\right)$

$\mathrm{t}=$ Time (hr or $\mathrm{min})$

$\mathrm{A}=$ Total area of kiln wall $=1.479 \mathrm{ft}^{2}$

$F_{C}=$ Effective Covering Fraction of the kiln wall by the sand (see Appendix A)

$\mathrm{m}_{\mathrm{s}}=$ Mass (lb) of sand (see run summary in Appendix A)

$m_{A}=$ Mass (lb) of auger blade assembly $=1.3 \mathrm{lb}$

$c=$ Specific Heat. For quartz and steel, averages are 0.25 and $0.12 \mathrm{Btu} / \mathrm{lb} /{ }^{\circ} \mathrm{F}$, respectively. Equivalent Specific Heat oil shale pyrolysis calculated from data in $\mathrm{RI}-7482: \mathrm{c}_{\text {oil sale }}=.33$ to .36 . $\mathrm{k}$ relates the heating rate of the interior metal to the heating rate of the sand $(k \approx 1)$.

Differential values, $\mathrm{dT} \& \mathrm{dt}$, are defined above.

Equation (1) can be rearranged, to illustrate the slope, as follows:

$$
\text { slope }=(d T / d t) / \text { DeltaT }=\mathrm{UAF}_{\mathrm{C}} /\left(\mathrm{m}_{\mathrm{S}} \mathrm{c}_{\mathrm{s}}+\mathrm{m}_{\mathrm{A}} \mathrm{c}_{\mathrm{A}} \mathrm{k}\right)
$$




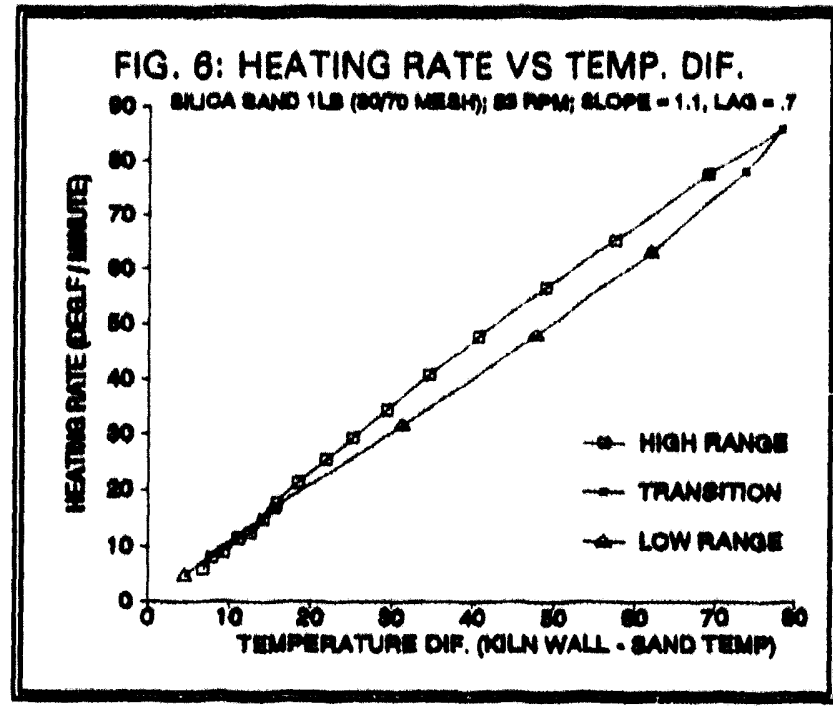

The slope of the sand temperature vs time, in the previous Fig. 5, corresponds to the heating rate, $\mathrm{dT} / \mathrm{dt}$. If that heating rate is plotted vs Delta $T$ (the Wall minus Sand Temperature), the result is the Fig. 6 curve with the same slope as on the left side of equation (2). On the right side of the equation, values for $A, F_{c}, m, c$ and $k$ are known. Thus $U$ can be calculated.

Radiation Effect: The graph of sand Heating Rate vs $\Delta \mathrm{T}$ (Fig. 6) exhibits a curious loop reminiscent of a hysteresis loop. Heating Rate and $\Delta \mathrm{T}$ both begin near 0 as the run starts at room temperature (Low Range). The curve increases to a maximum corresponding to the maximum heating rate (6 minutes, as noted in Fig. 5), during which the curve is undergoing a transition to a higher slope. As the furnace continues to heat past the maximum heating rate, the curve of Heating Rate vs $\Delta \mathrm{T}$ decreases and approaches 0 again as the kiln temperature equilibrates at the control temperature $\left(1000^{\circ} \mathrm{F}\right)$. The reason for the higher slope of the high temperature range (vs the low range) of Fig. 6 appears to be due primarily to the contribution from radiation at the higher temperatures.

To illustrate radiant heat transfer, we can add a radiation term, as a part of $U$, in equation (2). This term will then allow for the separation of effects of conduction and radiation. The term, $A \in \sigma\left[T_{W_{\text {all }}}{ }^{4}-\mathrm{T}_{\text {send }}{ }^{4}\right]$, can be included, where $T$ is the wall and sand temperatures, $A$ is the area exposed to radiation, $\epsilon$ is the net emissivity of internal surfaces and ranges from 0 to $1, \sigma$ is the Stefan-Boltzmann constant, $0.172 \times 10^{-8}$. It is convenient to divide the fourth power of absolute temperature by $10^{8}$, or $100^{4}$, and we have:

$$
\text { Radiation }=\mathrm{e}\left[\left(\mathrm{T}_{\text {Wall }} / 100\right)^{4}-\left(\mathrm{T}_{\text {Sand }} / 100\right)^{4}\right]
$$

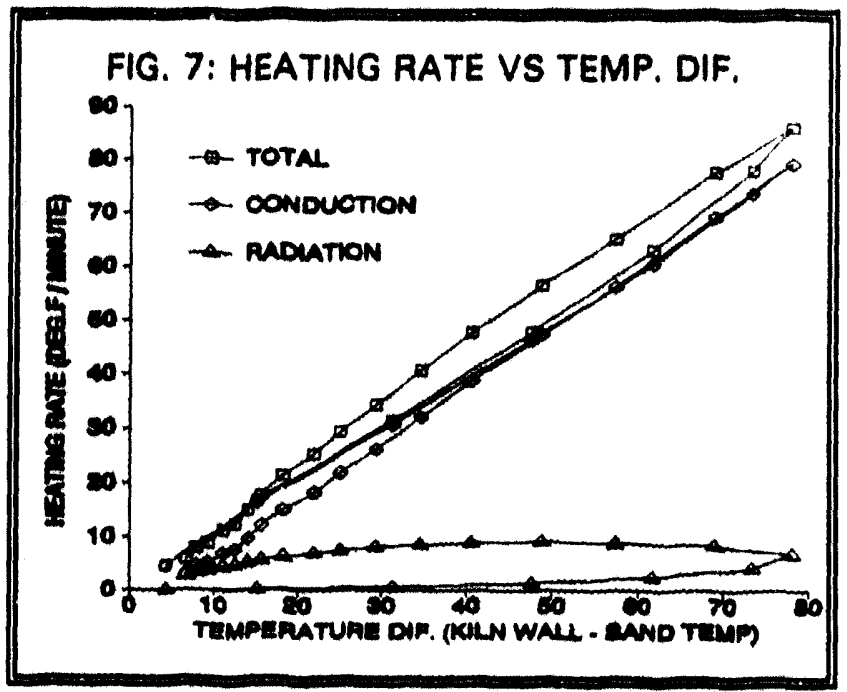

$A \epsilon$ and the antecedent of the $\sigma$ exponent, 0.172 , are combined into a single constant, $e$, which must be determined by experimentation, as the value providing the straightest conductivity curve. The conductivity curve is then expressed as:

$$
\text { SLOPE } E_{\text {COND }}=\left\{d T / d t-e\left[\left(T_{W_{\text {WII }}} / 100\right)^{4}-\left(T_{\text {Sand }} / 100\right)^{4}\right] /\left(m_{s} c_{s}+m_{A} c_{A} k\right)\right\} / \Delta T
$$

The resulting slope (Fig. 7) due to simple conductance is a straight line for all but an initial period of the low temperature leg, during which the system dynamics may not have been established. 
Heat Transfer Coefrient: To calculate the heat transfer coefficient, U, it is helpful to rearrange equation (2):

$$
U=\text { Slope }\left(m_{s} c_{s}+m_{A} c_{A} k\right) /\left(A F_{1}\right)
$$

Coefficient, $U$, was determined from the total average slope, as in Fig. 6, for over 50 sand runs made during this project. Values of $U$ vs Kiln Surface Velocity are plotted in Fig. 8. For comparison, the empirical data of Sullivan and Sabersky (discussed below) have been included. These runs were primarily 2 pound loads to establish the curve for the total velocity range. Runs with 1 and $4 \mathrm{lb}$ loads were also made to observe the effect of run size. (Appendix A summarizes all the run conditions and data used to calculate U.) Figure 8 is helpful to observe the effects of kiln velocity on heat transfer. Heat Transfer Coefficient increases rapidly with increase in Kiln Velocity up to about $140 \mathrm{ft} / \mathrm{min}$ where the curve peaks at about $107 \mathrm{Btu} / \mathrm{hr} / \mathrm{ft}^{2} /{ }^{\circ} \mathrm{F}$ ( $4 \mathrm{lb}$ load). At

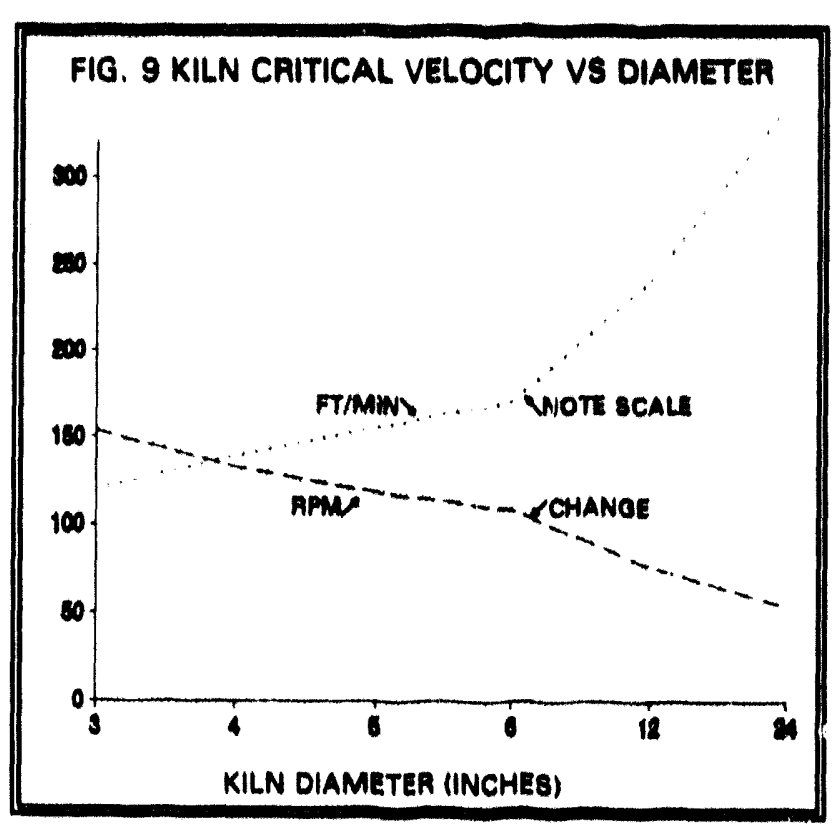
higher velocity the curve turns downward rapidly.

The reason for the decrease in heat transfer at high kiln velocity is due to two effects: (1) centrifugation which causes reduced sand mixing (the largest effect), and (2) shallow bed effects which cause reduced wall-particle contact.

Centrifupation: The critical surface velocity, $V_{c}$, is the velocity where flow of particles (sliding down the upwardly moving kiln surface) is disrupted by centrifugation whereupon the kiln contents are taken along with the moving wall. Centrifugation occurs above a $V_{c}$ that is a function of the kiln diameter or position that a particle is held from the kiln center. Fig. 9 is a graph of equivalent critical velocity functions: $V_{\text {CRrTICAL }}=241(\text { Diam })^{1 / 2} \mathrm{ft} / \mathrm{min}$, and 
$R P M_{\text {canricat }}=\left[5873\left(\mathrm{~N} / \mathrm{min}^{2}\right) / \operatorname{Diam}(\mathrm{ft})\right]^{1 / 2}$. The $R P M_{\mathrm{C}}$ curve shows that although centrifucation may begin at the kiln surface, e.8. at 115 RPM near the maximum kiln diameter of 5.4", particles may still flow and mix at positions closer to the kiln center not yet at critical RPM. For example at a position $1 / 2$ " from the wall, diameter $=4.4$ " and $R P M_{C}$ is 127 . So dthough particles begin centrifuging at the surface (5.4"), flow may still continue at higher RPM nearer the center. Thus heat transfer in Fig. 9 is reducing rapidly at $V_{C}$ of 160 but the slope continues beyond $160 \mathrm{ft} / \mathrm{min}$. Surface irregularities in the kiln (e.g. leading edges of auger blades and thermocouples) may tend to cause centrifugation at lower RPM than would occur without the irregularities. This point is significant to this project because the auger blades are a smoother design than was used in 1987, consequently the heat transfer peak is shined to a higher RPM.

Rutgers has described mechanisms of bed motion in a horizontal cylindrical kiln in cerms of the ratio of kiln RPM to the critical RPM ${ }_{C}$. He showed that effects and flow regimes can be predicted on the basis of this ratio. The peak at $140 \mathrm{ft} / \mathrm{min}$ is $87 \%$ of the critical velocity of $160 \mathrm{ft} / \mathrm{min}$ and it is likely that this fraction is significant for the auger asembly, or similar one, used in this or similar kilns.?

Shullow Bed Phenomena: Data for Heat Conductance of particles flowing on a flat plate, Fig. 10, Is reconstructed from data of Sullivan and Sabersky, and Spelt et al..$^{8,9}$ They refer to the work of Botterill and Desai ${ }^{10}$ who previously noted that the particle packing density near the wall is a governing factor for heat transfer to fluidized or flowing beds. Spelt et al. note that as velocity increases, at some point the increasing particle mobility is accompanied by a decrease in packing density and heat transfer. Thus as velocity increases, in Fig. 10, the heat transfer reaches a maximum and then curves downward. The greater pressure from larger bed depths tends to maintain the packing density and so accounts for the higher peaks for deeper beds.

Although centrifugation counteracts the

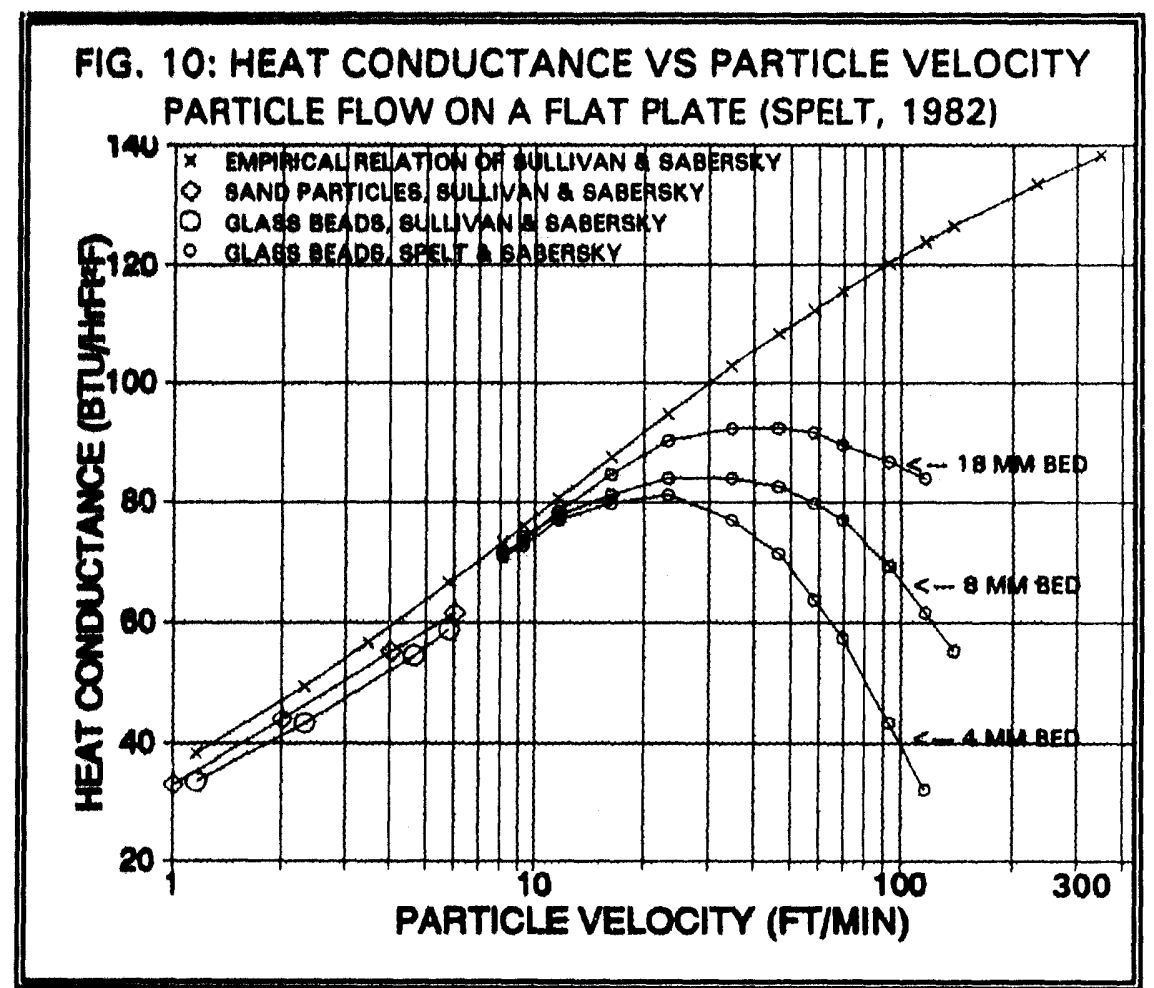
reduced packing density to a degree, it appears that the latter effect may account for the low heat transfer values for small loads ( $1 \& 2 \mathrm{lb}$ loads), as observed in Fig. 8. A normalizing feature can be included in equation (2) so 1 and 2 pound load curves can be normalized to the 4 pound curves by raising $F_{C}$ to a power, $F_{c}{ }^{p}$. We normalize to the larger load data since our interest is in larger kilns (and deeper beds). A statistical procedure helped to 
accurately establish the value (of $\mathbf{P}=1.25$ ) to minimize the data spread. A constant, $\mathrm{C}=$ 0.8 , counter-adjusts the magnitude of $U$ which would otherwise increase with increasing $P$. Thus we have equation (3) which was used to calculate the results in Fig. 11 wherein the three different load sizes fall in the same range.

$$
U=C \text { Slope }\left(m_{s} c_{s}+m_{A} c_{A} k\right) /\left(A F_{C}{ }^{P}\right)
$$

Heat Transfer--Oil Shale Runs: Twelve retorting runs were made on the five different oil shales in the kiln. The average heat transfer in the rotary kiln was 78 $\mathrm{Btu} / \mathrm{hr} / \mathrm{ft}^{2} /{ }^{\circ} \mathrm{F}$ for $8 \mathrm{Green}$ River runs. It was 74 for 3 Eastern oil shales. Heat transfer for the retorted oil shale combustion is included in Fig. 11 and is very close to the same value for Green River oil shale retorting. The average net heat transfer in the continuous process kiln (with oil shale on the inside of the Heat Conducting Wall and burning spent oil shale outside a $1 / 16^{\prime \prime}$ stainless steel wall) net heat FIG. 11: HEAT TRANSFER COEF. VS SURFACE VELOCITY ROTARY KILN RUNS NCLUOING OIL SHALE AND SPENT SHALE

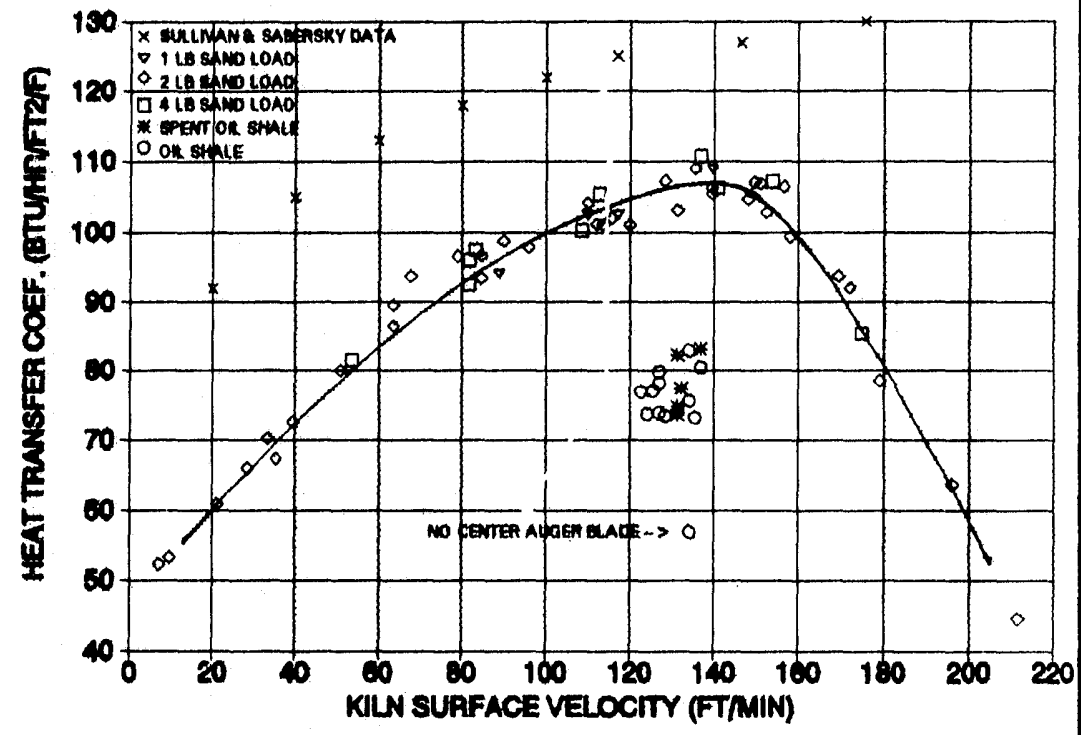

transfer would be $38 \mathrm{Btu} / \mathrm{hr} / \mathrm{ft}_{2} /{ }^{\circ} \mathrm{F}$. This is about $5 \%$ lower than previous estimates. ${ }^{11}$

In this context, Fig. 9 also illustrates that the critical velocity increases with increasing kiln diameter. Note that a $12^{\prime \prime}$ diameter kiln has a $V_{C}$ of $241 \mathrm{ft} / \mathrm{min}$. Deep particle beds in larger kilns and intense mixing that occurs in rotating kilns will add to the effects promoting

\begin{tabular}{|c|c|c|c|}
\hline \multicolumn{4}{|c|}{$\begin{array}{c}\text { TABLE I: KILN RUN RESULTS } \\
\text { AS } \% \text { OF FISCHER ASSAY }\end{array}$} \\
\hline & OAf Yietd & Oil Density & Ges \\
\hline Occidental 2 & 111 & 103 & 59 \\
\hline Occidental 3 & 108 & 103 & 75 \\
\hline Occidental 4 & 109 & 103 & 52 \\
\hline Parachute 1 & 110 & 104 & 85 \\
\hline Parachute 2 & 112 & 104 & 90 \\
\hline Tipton 1 & 103 & 106 & 82 \\
\hline Tipton 2 & 106 & 105 & 65 \\
\hline Tipton 3 & 105 & 105 & 86 \\
\hline Kentucky 1 & 114 & 106 & 46 \\
\hline Kentucky 2 & 117 & 105 & 59 \\
\hline Indiana 1 & 106 & 106 & 79 \\
\hline Indiana 2 & 102 & 106 & 76 \\
\hline AVG. $\%$ of F.A. & 108.6 & 105 & 71 \\
\hline
\end{tabular}
heat transfer. On the basis of the empirical relation of Sullivan and Sabersky (Fig. 11) ultimate CHESS process heat transfer may possibly increase by $20 \%$ or more above the values observed for this small kiln. If so it would increase net heat transfer from 38 to the range of 40 to $50 \mathrm{Btu} / \mathrm{hr} / \mathrm{ft}^{2} /{ }^{\circ} \mathrm{F}$.

\section{Oil Shale Retorting}

High Oil Yield: One of the very positive results of this project is the demonstration of high oil yield. Average oil yield was $108.6 \%$ of Fischer Assay. All 12 oil shale runs were significantly higher yield than Fisher Assay. The lowest yield was the Indiana \#2 run, at $102 \%$ of Fischer Assay, possibly because it 
was an irregular run, as was noted previously. However, for oil yield, Indiana \#2 was averaged together with the other runs.

High oil yield is also indicated, in the Table I summary results (of Appendices B and C), by two additional sets of data which are consistent with high oil yield. These are high Oil Density and low Gas production. These three effects are all indications of a low degree of oil reforming and cracking. These are the natural result of the rotary kiln system with ample mixing, good gas-solid contacting and an effective sweepgas - features absent from the Fischer Assay system. Additional CHESS kiln effects common to the Fischer Assay but not common to recycled ash systems are: the momentous absence of the high surface area of the coke-promoting hot recycle ash; and the immediate evacuation and cooling of the oil vapor at

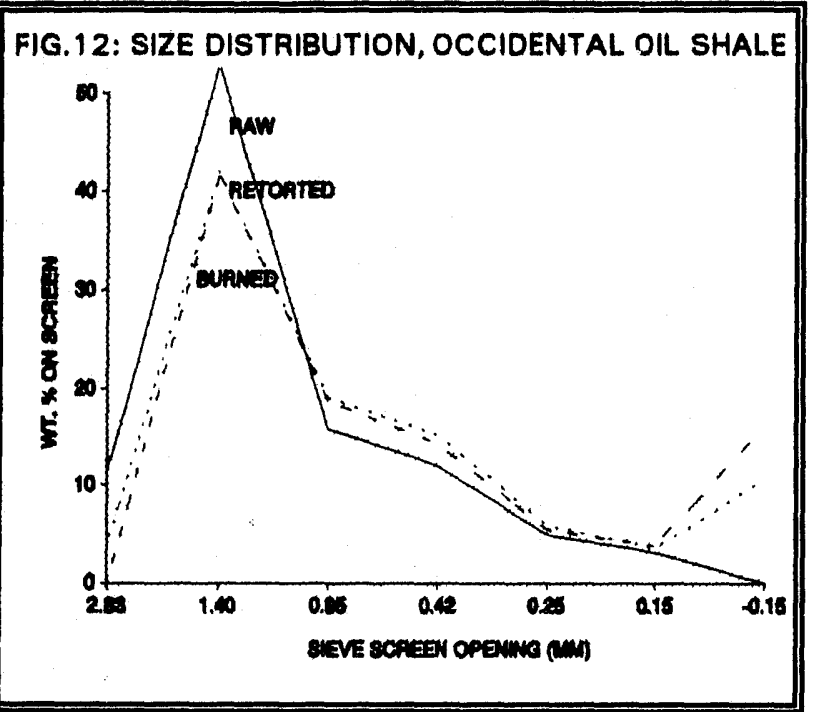
relatively low temperatures (the formation temperature from $700^{\circ}$ to $900^{\circ} \mathrm{F}$ vs about $1300^{\circ} \mathrm{F}$ for hot recycled ash). All the analytical data for the oil shale samples before and after retorting and after oxidation runs are included in Appendix C.

Kiln Plugging Tendency was defined in the 1987 Tar Sand project as the percent of residual solids that adheres firmly to the kiln at the end of the run. In the Tar sand runs, plugging percentages ranged from 3 to $25 \%$. The most important finding of this work is that all of the 12 oil shale runs exhibited zero plugging tendency or a complete absence of any kiln surfaceadhering solids. This is positive

information for the success of the Adams CHESS kiln and it confirms and extends the limited oil shale data (one oil shale run) of the 1987 tar sands project.

Particle agglomeration and growth, if it should occur to a great extent, is a second kind of plugging, that could occur in the CHESS kiln. To show that agglomeration would not occur when processing various ores, size distribution of the samples was determined for each ore before and after retorting and after burning. All retorted samples exhibited the tendency illustrated in Fig. 12 for Occidental oil shale (see Appendix D), wherein the particle distribution shifted slightly toward smaller particles during retorting. Although particles are known to agglomerate in packed bed retorts, we should anticipate no plugging due to particle agglomeration in the rotary kiln.

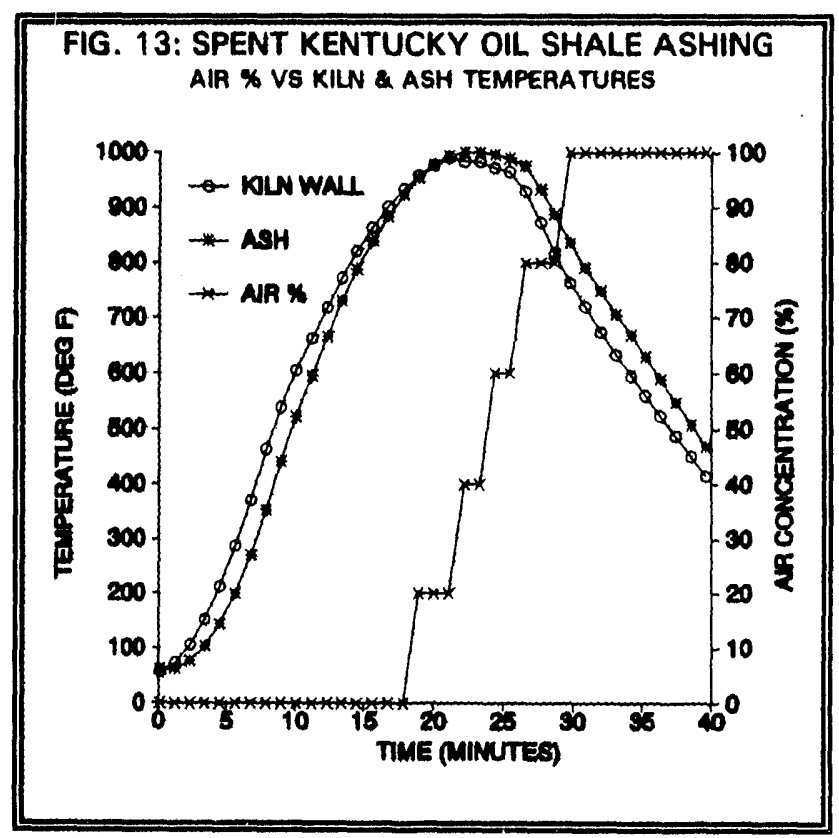


Spent Oil Shale Coke Combustion ${ }^{12}$ : Five spent oil shale runs, one run with each of the five oil shales, were burned in a variable mixture of nitrogen and air. The runs were first taken to $1000^{\circ} \mathrm{F}$ in $100 \%$ nitrogen. Then gradually increasing amounts of air were mixed with the nitrogen sweep gas in a program to simulate the continuous process kiln, as shown in Fig. 12 for oxidation of Kentucky spent shale. In the CHESS process kiln, the newly retorted oil shale contacts a lean air mixture in combustion gas. The mixture gradually becomes richer in air as the burning shale flows counter-current to the feed air.

Carbon Conversion-Pyrolysis: Table II provides a summary of (Appendices C and G), carbon conversion data for retorting and combustion runs in the kiln. Retorting normally converts 73 to $81 \%$ of Green River oil shale carbon to liquid and gas, the rest remaining in the spent shale as coke. Singleton et al. have shown that Green River oil shale conversion is moderately dependant on the ore grade, lean grades converting a lower percentage of the kerogen. ${ }^{13}$ That effect is borne out in this study. Column B shows the carbon converted by retorting. The low grade ores converted the lowest percentage of organic carbon (in the order: Occidental < Tipton < Parachute).

Coke oxidation: The percent of the spent shale carbon that was converted by combustion

\begin{tabular}{|c|c|c|c|c|c|c|}
\hline \multicolumn{7}{|c|}{ TABLE II: ORGANIC CARBON CONVERSION DATA } \\
\hline & A & $\mathbf{B}$ & C & D & $\mathbf{E}$ & $\mathbf{F}$ \\
\hline Sample & $\begin{array}{l}\text { Grado } \\
\text { (gpt) }\end{array}$ & $\begin{array}{l}\text { \% RSOC } \\
\text { Retorted }\end{array}$ & $\begin{array}{r}\% \text { Ssoc } \\
\text { Bumned }\end{array}$ & $\begin{array}{r}\text { Tot. AsOC } \\
\text { Peactod }\end{array}$ & $\begin{array}{l}\text { Min. } \\
\text { Grado }\end{array}$ & $\begin{array}{c}\% \mathrm{C} \\
X C E S\end{array}$ \\
\hline Occidental & 18.2 & 76 & 69 & 92 & 14.1 & 30 \\
\hline Parachute & 28.2 & 81 & 69 & 94 & 14.1 & 100 \\
\hline Tipton & 20.3 & 79 & 60 & 91 & 19.3 & 5 \\
\hline Kentucky & 13.4 & 48 & 55 & 77 & 2.1 & 540 \\
\hline Indiana & 13.9 & 48 & 21 & 59 & 7.8 & 80 \\
\hline \multicolumn{7}{|c|}{ 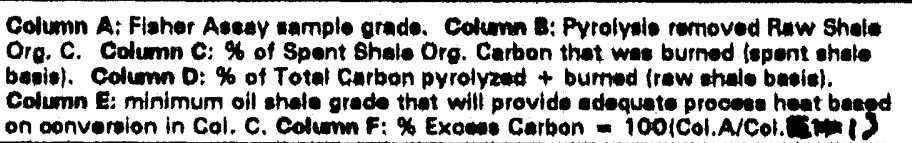 } \\
\hline
\end{tabular}
is given in Column $\mathbf{C}$ and indicates the efficiency of the combustion. Two limitations of the combustion were the size of the particles during combustion and inactivity of the Eastern oil shale residue. The larger particles $(3 \mathrm{~mm})$ were dark in the center and light near the surface indicating complete burning occurred at the particle periphery but not in the center. The particles smaller than $1 \mathrm{~mm}$ appeared to have burned more completely. This observation may indicate that for applications where complete carbon combustion is desired, the particle size should be approximately $1 \mathrm{~mm}$ and smaller.

A smaller maximum size will not markedly detract from the claim of relatively large effluent particle size for the CHESS process. For although the maximum size may be smaller than previously anticipated, the process fines will still be relatively fewer as compared to recycled ash conditions that generate fines. These conditions are: (1) rapid particle heatup which causes particle-bursting decrepitation, and (2) high temperature, above $1000^{\circ} \mathrm{F}$, where the mineral carbonates decompose to ultra-fine particles. It has been noted by Barney and Carlson "Upon decomposition of the carbonates, the residue or shale ash is converted to an extremely fine (50-90 wt. \% -44 micron), porous and oleophilic material. ${ }^{14}$ And of course, it is the very fine particles that are difficult to manage.

It is anticipated that by adjusting the maximum particle size and using the appropriately higher temperature, in the case of Eastern shales, the burning efficiency will be much higher, possibly $90 \%$ or above.

Excess Process Heat: All the ashing runs exhibited excess heat for the CHESS process. Although the Eastern oil shales are very low oil grade, the spent shales are carbon rich. 
Even with very low carbon oxidation of $21 \%$, the lndiana sample still had $80 \%$ excess heat. (Note the explanations at the table bottom. The calculations for Column $E$ are provided in Appendix G.)

The degree of oxidation of the carbon on the spent shale, though less than $100 \%$, is still a momentous success, showing that the carbon on lean grade ores can drive the CHESS process and provide excess heat. The degree to which the coke in the runs was oxidized was also a function of the oil shale type and oxidizing temperatures. While $1000^{\circ} \mathrm{F}$ will be adequately hot to process Green River oil shale, some Eastern oil shales will probably need to be oxidized at temperatures 100-300 degrees hotter for complete oxidation of the coke.

Ash Alkalinity: Before processing, the alkalinity for all five oil shale samples was neutral $(\mathrm{pH}=7)$. Upon processing, the ash $\mathrm{pH}$ increased to 9 and 11 for the Parachute and Tipton samples respectively. All the other samples, Occidental, Kentucky and Indiana, had not changed $\mathrm{pH}$. While all the Green River oil shales have a large fraction of mineral carbonates, they would be only slightly affected below $1000^{\circ} \mathrm{F}$, as was the Occidental sample. The Parachute sample maximum temperature was $1037^{\circ} \mathrm{F}$ during pyrolysis (Appendix B) which may have caused some carbonate calcination to account for the raised $\mathrm{pH}$ of 9. The Tipton sample maximum was only $1000^{\circ} \mathrm{F}$. The thermogravimetric analysis of the Tipton sample had a weight loss peak at about $600^{\circ} \mathrm{F}$, before the hydrocarbon peak began to evolve and this seems to indicate the presence of a minera! such as dawsonite. Dawsonite would decompose at around $600^{\circ} \mathrm{F}$ to form sodium carbonate and could possibly account for the high $\mathrm{pH}$ of 11 . Dawsonite is a desirable aluminum ore and would likely be removed prior to retorting if it is found in significantly large amounts. Careful control of the process below $1000^{\circ} \mathrm{F}$ should produce product ash of desirably low alkalinity.

\section{Environinental Impact}

CHESS process heat recovery will reduce the combustion product by the same amount is the heat recovered, 80 to $90 \%$ of process heat (see Appendix G). Scrubbers and gas cleanup requirements will thus be greatly reduced for the CHESS process. Low temperature pyrolysis and combustion will minimize the alkatine calcination of mineral carbonates in Western oil shales. Combustion of the coke on the spent shale will help strip the polyaromatic hydrocarbons from the ash and reduce the amount of this known contaminant. ${ }^{15}$ Where other processes would depend on water cooling, Counter-current heat exchange in solid streams will markedly conserve water. Thus, lower heat requirements and the low temperature of the CHESS process equate to the mitigation of the environmental impact of oil shale processing.

Needed Development: The U.S. imports nearly 3 billion barrels of oil, at a cost of over $\$ 50$ billion per year, causing a strain on the U.S. balance of payments and jeopardizing our national security. The demand for oil is increasing as world oil supplies, especially the domestic share, are decreasing. It is estimated that U.S. production will decrease $80 \%$ by the year 2010. ${ }^{16}$ Increasing oil prices, gradual or sudden, are inevitable, probably within the next ten to fifteen years. Ample resources are available in the Green River oil shale reserves to supply the U.S. needs for over a hundred years.

The CHESS process has the potential to develop shale oil more economically and with less environmenta! impact than other current methods. The demonstration of this new shale oil technology, '́rom the Process Development Unit (PDU) to Demonstration Plant stage 
would require approximately ten years. With the success of the current project research, construction of a small PDU is necessary to demonstrate the CHESS process features in a continuously operating unit.

\section{CONCLUSIONS}

The following observations, in order of importance to the success of the CHESS process, can be made at the conclusion of this phase of the project:

(1) All of the oil shale runs, 12 operational, as well as all preliminary debugging oil shale runs, were attended by a complete absence of kiln surface-adhering solids. There was no particle agglomeration in any of the runs.

(2) Process simulation runs burned 60 to $70 \%$ of the coke from the Green River spent oil shales and 20 to $55 \%$ of the Eastern spent oil shales. This level would provide ample heat for processing oil shales of $20 \mathrm{gal} / \mathrm{ton}$ and much leaner after process optimization.

(3) The overall Heat Transfer Coefficient for the Process Development kiln (1/16" wall) will be in the range of 40 to $45 \mathrm{Btu} / \mathrm{hr} / \mathrm{ft}^{2} /{ }^{\circ} \mathrm{F}$.

(4) Average oil yield was (a desirably high) $108.6 \%$ of Fisher Assay.

(5) Calculations indicate that this level of heat transfer will provide for $80 \%$ of the heat requirements and spent shale coke combustion can provide for the other $20 \%$, with much heat to spare, even with very lean oil shale grades.

(6) The success of the above features predicts an environment-friendly shale oil recovery process.

With the demonstration of these positive features, the immediate imperative is to go forward with the development of a continuous process development. 


\section{NOTES AND REFERENCES}

1. The CHESS process was formerly referred to as Counter Current Solid Streams Heat Transfer (CCSSHT). The name was changed in response to the suggestion of one of the principals at the 1991 DOE sponsored Commercialization Workshop (Austin, Texas), that the process needed a better name. More than an easier to pronounce acronym, the name "CHESS" brings to mind an intellectual, strategically designed approach. So the name is appropriate to this process, the only oil shale process designed at the outset for efiiciency. It is an obvious fact that heat recovery must be a big part of any successful oil shale process. Nevertheless, most shale oil process designs relegate heat recovery to an afterthoug it position, a unit operations add-on, after everything else is considered. Except for the CHESS process, only the Taciuk retort uses heat recovery as an integral part of the retort. But the Taciuk retort recycles the hot ash (a co-current , , peration) and recovers heat only in a minor and inefficient way.

2. Abstracts of the 1987 and 1990 projects were published in Small Business Innovation Research, Abstracts of Phase I Awards, SBIR Program Mgr., Office of Energy Research, U.S. DOE, Wash., D.C. 20545. 1987, page 45, and 1990, page 16. The project reports are available through NTIS (3 yrs. after submission, i.e. 1991 and 1994), or by contacting Energy Recov. Tech., 886 Monument Park Circle, SLC, UT 84108.

3. For details of the CHESS Retort design, see D. C. Adams, A High Efficiency Retort to Recover Shale Oil, A Proposal for an $R$ \& $D$ Project to Demonstrate the Feasibility of a High Efficiency Oil Shale Kiln; Submitted to the NIST, December 1989, Recommendation \# 533, DOE OERI \# 013721.

4. M. Desai, Ph.D. Dissertation, Univ. of Birmingham, England (1970).

5.This elaborate chain of grinding and subdividing in multiple stages is to provide ample fine particles after subsequently subdividing the heterogeneous material. This care was used to ensure that a subdivided sample be fine enough so that even if all the particles were maximum size from the sieve, at least 10,000 particles would be in the subdivision to promote high probability of uniformity between samples, or that the subdivided sample would be representative of the larger sample. The fine size of -100 mesh was requested by WRI for their analyses of CHN \& Mineral Carbon. This fine size is consistent with a 10,000 particle sample if the CHN samples are no smaller than 33 milligrams.

6. Measurement of organic sulfur and oxygen presents a significant problem beyond the scope and need of this project. Organic sulfur is usually obtained by first determining the total sulfur then subtracting determinations of the different forms of mineral sulfur, primarily pyrite $\left(\mathrm{FeS}_{2}\right)$ and sulfates (e.g. $\left.\mathrm{CaSO}_{4}\right)$, sometimes including traces of marcasite $\left(\mathrm{FeS}_{2}\right)$ and pyrrhotite or toilite (FeS). Organic sulfur is normally a small fraction, less than $1 \%$ of oil shale and in one sample it was just $1 \%$ of the kerogen content. But it varies greatly perhaps as a result of the proximity to mineral sulfur. Organic oxygen presents an even greater problem. It is usually determined by subtracting the non-oxygen components from the total 
weight. Thus the error of the oxygen analysis would contain the sum of all the error including any mineral nitrogen, which is sometimes present.

7. R. Rutgers, Chem. Eng. Sci. 20, 1089, (1965). It should be noted that the 1987 project used a very different auger assembly. It used multiple short auger blade sections, no center auger blade and the kiln was set at a $7^{\circ}$ angle to promote flow through the center. Not surprisingly, the peak heat transfer occurred at a low $40 \%$ of the critical velocity.

8. W. N. Sullivan and R. H. Sabersky, Int. J. Heat Mass transfer Vol. 18. pp. 97-107, (1973).

9. J. K. Spelt, et al. "Heat Transfer to Flowing Granular Material," Int. J. Heat Mass

Transfer. Vol. 25, No. 6. $791-796$ (1982). This study was for glass beads on a flat plate but it extended the data of Sullivan and Sabersky to higher surface velocities.

10. J. S. M. Botterill, and M. Desai, "Limiting factors in gas-fluidized bed heat transfer," Powder Technology, 6, 231 (1972).

11. A value of $40 \mathrm{Btu} / \mathrm{hr} / \mathrm{ft}^{2} /{ }^{\circ} \mathrm{F}$ was previously estimated in Appendix B of the project proposal, Ref. 3.

12. As used in this report the words "combustion" and "burn" should be understood in the alternate dictionary sense of "slow oxidation and little light."

13. M.F. Singleton, et al. Assay Products from Green River Oil Shale, UCRL-53273, Rev. 1 (1986).

14. J. H. Barney and F. B. Carlson, Quoted in Oil from Shale and Tar Sands, E. M. Perrini, Noyes Data Corp. 1975, p. 93.

15. For example, see discussion by J. J. Schmidt-Collerus, The Disposal and Environmental Effects of Carbonaceous Solid Wastes from Commercial Oil Shale Operations, Denver Res. Inst., Jan. 1974. NTIS Doc. \# PB-231 796.

16. H. Robb, Final Technical Review; A High Efficiency Retort To Recovery Shale Oil, OERI \# 13721, page 2. See Proposal, Ref. 3. 
APPENDIX A: SUMMARY OF KILN RUN HEAT TRANSFER CALCULATION DATA

\begin{tabular}{|c|c|c|c|c|c|c|c|c|c|c|}
\hline Material & $\begin{array}{l}\text { Run \& } \\
\text { File } "\end{array}$ & $\begin{array}{l}\text { Solids } \\
\text { Load } \\
\text { (lb) }\end{array}$ & $\begin{array}{c}\text { Solids } \\
\text { BultrDons } \\
\text { (1b/in') }\end{array}$ & $\begin{array}{l}\text { Solids } \\
\text { Volume } \\
\text { (Culn) }\end{array}$ & $\begin{array}{l}\text { Filled } \\
\text { Praction } \\
\text { Pf }\end{array}$ & $\begin{array}{c}\text { Covered } \\
\text { Fruction } \\
\text { Fe }\end{array}$ & $\begin{array}{c}\text { Slope } \\
\text { (Ht. Rate } \\
\text { vo DeltaT) }\end{array}$ & RPM & $\begin{array}{l}\text { Surfuce } \\
\text { Velooity } \\
\text { (PV/min) }\end{array}$ & $\begin{array}{c}\text { HLTran. } \\
\text { Coef. } \\
\text { (U) }\end{array}$ \\
\hline \multicolumn{11}{|c|}{ SAND RUNS } \\
\hline 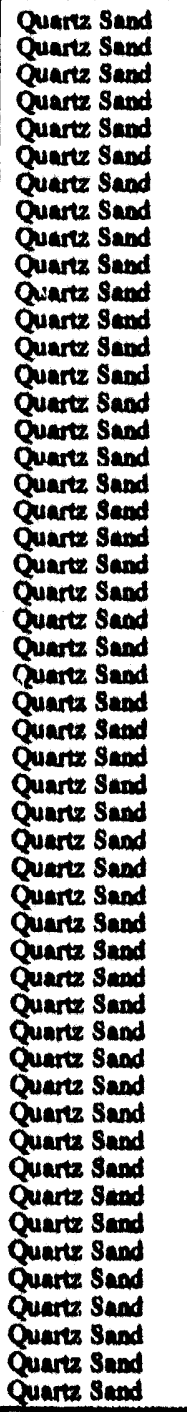 & 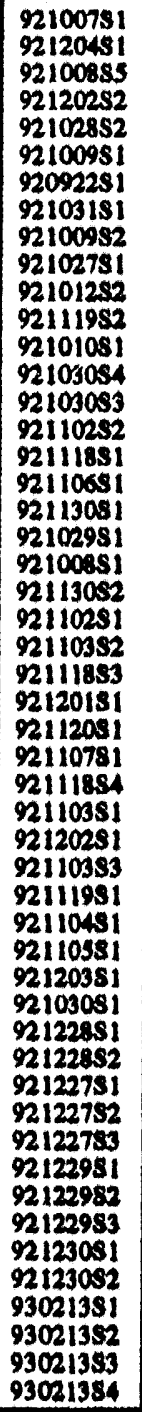 & $\begin{array}{l}2.203 \\
2.203 \\
2.203 \\
2.203 \\
2.203 \\
2.203 \\
2.203 \\
2.203 \\
2.203 \\
2.203 \\
2.203 \\
2.203 \\
2.203 \\
2.203 \\
2.203 \\
2.203 \\
2.203 \\
2.203 \\
2.203 \\
2.203 \\
2.203 \\
2.203 \\
2.203 \\
2.203 \\
2.203 \\
2.203 \\
2.203 \\
2.203 \\
2.203 \\
2.203 \\
2.203 \\
2.203 \\
2.203 \\
2.203 \\
2.203 \\
2.203 \\
2.203 \\
3.982 \\
3.982 \\
3.992 \\
3.982 \\
3.983 \\
3.902 \\
3.902 \\
3.992 \\
3.992 \\
3.992 \\
1.322 \\
1.320 \\
1.322 \\
1.320 \\
\end{array}$ & $\begin{array}{l}0.048 \\
0.048 \\
0.048 \\
0.048 \\
0.048 \\
0.048 \\
0.048 \\
0.048 \\
0.048 \\
0.048 \\
0.048 \\
0.048 \\
0.048 \\
0.048 \\
0.048 \\
0.048 \\
0.048 \\
0.048 \\
0.048 \\
0.048 \\
0.048 \\
0.048 \\
0.048 \\
0.048 \\
0.048 \\
0.048 \\
0.048 \\
0.048 \\
0.048 \\
0.048 \\
0.048 \\
0.048 \\
0.048 \\
0.048 \\
0.048 \\
0.048 \\
0.048 \\
0.048 \\
0.048 \\
0.048 \\
0.048 \\
0.048 \\
0.048 \\
0.048 \\
0.048 \\
0.048 \\
0.048 \\
0.048 \\
0.048 \\
0.048 \\
0.048\end{array}$ & $\begin{array}{l}46.0 \\
46.0 \\
46.0 \\
46.0 \\
46.0 \\
46.0 \\
46.0 \\
46.0 \\
46.0 \\
46.0 \\
46.0 \\
46.0 \\
46.0 \\
46.0 \\
46.0 \\
46.0 \\
46.0 \\
46.0 \\
46.0 \\
46.0 \\
46.0 \\
46.0 \\
46.0 \\
46.0 \\
46.0 \\
46.0 \\
46.0 \\
46.0 \\
46.0 \\
46.0 \\
46.0 \\
46.0 \\
46.0 \\
46.0 \\
46.0 \\
46.0 \\
46.0 \\
83.1 \\
83.1 \\
83.1 \\
83.1 \\
83.1 \\
83.1 \\
83.1 \\
83.1 \\
83.1 \\
83.1 \\
27.6 \\
27.6 \\
27.6 \\
27.6\end{array}$ & $\begin{array}{l}0.202 \\
0.202 \\
0.202 \\
0.202 \\
0.202 \\
0.202 \\
0.202 \\
0.202 \\
0.202 \\
0.202 \\
0.202 \\
0.202 \\
0.202 \\
0.202 \\
0.202 \\
0.202 \\
0.202 \\
0.202 \\
0.202 \\
0.202 \\
0.202 \\
0.202 \\
0.202 \\
0.202 \\
0.202 \\
0.202 \\
0.202 \\
0.202 \\
0.202 \\
0.202 \\
0.121 \\
0.202 \\
0.121 \\
0.202 \\
0.202 \\
0.202 \\
0.202 \\
0.202 \\
0.365 \\
0.303 \\
0.363 \\
0.365 \\
0.365 \\
0.365 \\
0.365 \\
0.365 \\
0 .\end{array}$ & $\begin{array}{l}0.309 \\
0.309 \\
0.309 \\
0.309 \\
0.309 \\
0.309 \\
0.309 \\
0.309 \\
0.309 \\
0.309 \\
0.309 \\
0.309 \\
0.309 \\
0.309 \\
0.309 \\
0.309 \\
0.309 \\
0.309 \\
0.309 \\
0.309 \\
0.309 \\
0.309 \\
0.309 \\
0.309 \\
0.309 \\
0.309 \\
0.309 \\
0.309 \\
0.309 \\
0.309 \\
0.309 \\
0.309 \\
0.309 \\
0.309 \\
0.309 \\
0.309 \\
0.309 \\
0.418 \\
0.418 \\
0.418 \\
0.418 \\
0.418 \\
0.418 \\
0.418 \\
0.418 \\
0.418 \\
0.418 \\
0.244 \\
0.244 \\
0.244\end{array}$ & $\begin{array}{l}0.523 \\
0.533 \\
0.609 \\
0.660 \\
0.702 \\
0.673 \\
0.726 \\
0.895 \\
0.800 \\
0.864 \\
0.937 \\
0.965 \\
0.964 \\
0.934 \\
0.987 \\
0.974 \\
1.041 \\
1.011 \\
1.010 \\
1.020 \\
1.010 \\
1.072 \\
1.030 \\
1.090 \\
1.054 \\
1.062 \\
1.047 \\
1.070 \\
1.028 \\
1.068 \\
0.993 \\
1.064 \\
0.937 \\
0.920 \\
0.785 \\
0.636 \\
0.446 \\
0.898 \\
0.972 \\
0.829 \\
0.730 \\
0.765 \\
0.958 \\
0.960 \\
0.944 \\
0.873 \\
1.110 \\
\end{array}$ & 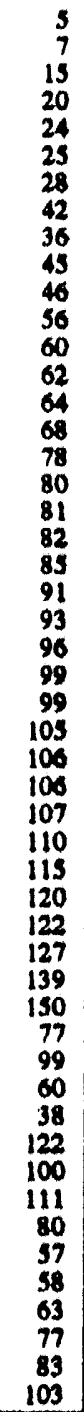 & $\begin{array}{r}7 \\
10 \\
21 \\
28 \\
33 \\
35 \\
39 \\
63 \\
51 \\
63 \\
65 \\
79 \\
85 \\
85 \\
90 \\
96 \\
110 \\
112 \\
114 \\
116 \\
120 \\
128 \\
131 \\
135 \\
140 \\
140 \\
148 \\
149 \\
149 \\
151 \\
155 \\
162 \\
169 \\
172 \\
179 \\
196 \\
212 \\
109 \\
140 \\
85 \\
54 \\
172 \\
141 \\
157 \\
113 \\
80 \\
82 \\
89 \\
109 \\
117 \\
145\end{array}$ & $\begin{array}{c}52 \\
53 \\
61 \\
60 \\
70 \\
67 \\
73 \\
90 \\
80 \\
86 \\
94 \\
97 \\
97 \\
93 \\
99 \\
98 \\
104 \\
101 \\
101 \\
102 \\
101 \\
107 \\
103 \\
109 \\
105 \\
106 \\
105 \\
107 \\
103 \\
107 \\
99 \\
106 \\
94 \\
92 \\
79 \\
64 \\
45 \\
101 \\
111 \\
93 \\
82 \\
80 \\
102 \\
107 \\
107 \\
106 \\
98 \\
96 \\
94\end{array}$ \\
\hline \multicolumn{11}{|c|}{ OL SHALE AND O.S. RESIDUE (ASH) RUNS } \\
\hline 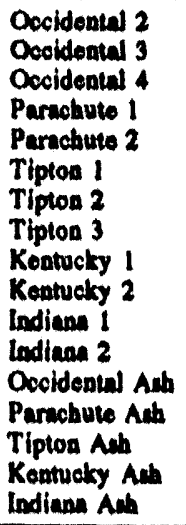 & 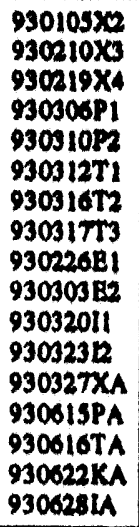 & $\begin{array}{l}2.206 \\
2.282 \\
2.143 \\
2.127 \\
2.227 \\
2.143 \\
2.114 \\
2.019 \\
2.405 \\
2.235 \\
2.167 \\
2.183 \\
1.636 \\
1.323 \\
1.773 \\
1.960 \\
1.704\end{array}$ & $\begin{array}{l}0.038 \\
0.038 \\
0.038 \\
0.037 \\
0.037 \\
0.037 \\
0.037 \\
0.037 \\
0.039 \\
0.039 \\
0.038 \\
0.038 \\
0.042 \\
0.038 \\
0.039 \\
0.040 \\
0.036\end{array}$ & $\begin{array}{l}58.7 \\
60.2 \\
56.6 \\
57.6 \\
60.3 \\
58.2 \\
57.4 \\
54.8 \\
61.8 \\
57.5 \\
57.7 \\
58.1 \\
38.7 \\
35.2 \\
45.4 \\
48.9 \\
46.7\end{array}$ & $\begin{array}{l}0.258 \\
0.265 \\
0.249 \\
0.253 \\
0.205 \\
0.256 \\
0.252 \\
0.241 \\
0.272 \\
0.253 \\
0.254 \\
0.256 \\
0.170 \\
0.155 \\
0.200 \\
0.215 \\
0.205\end{array}$ & $\begin{array}{l}0.348 \\
0.353 \\
0.342 \\
0.345 \\
0.353 \\
0.347 \\
0.344 \\
0.337 \\
0.357 \\
0.345 \\
0.345 \\
0.346 \\
0.285 \\
0.273 \\
0.307 \\
0.318 \\
0.311\end{array}$ & $\begin{array}{l}0.672 \\
0.697 \\
0.707 \\
0.730 \\
0.696 \\
0.743 \\
0.700 \\
0.730 \\
0.660 \\
0.666 \\
0.666 \\
0.530 \\
0.812 \\
0.805 \\
0.790 \\
0.820 \\
0.800\end{array}$ & $\begin{array}{l}88 \\
87 \\
89 \\
95 \\
90 \\
97 \\
95 \\
90 \\
90 \\
91 \\
96 \\
95 \\
93 \\
93 \\
95 \\
97 \\
93\end{array}$ & $\begin{array}{l}124 \\
123 \\
125 \\
134 \\
127 \\
137 \\
134 \\
127 \\
127 \\
128 \\
135 \\
134 \\
131 \\
131 \\
132 \\
137 \\
131\end{array}$ & $\begin{array}{l}74 \\
77 \\
77 \\
83 \\
80 \\
81 \\
76 \\
78 \\
74 \\
74 \\
73 \\
57 \\
82 \\
74 \\
77 \\
83 \\
75\end{array}$ \\
\hline
\end{tabular}




\section{APPENDIX B}

\section{SUMMARY OF PYROLYSIS RUN FEED AND PRODUCT DATA}

1993 OIL SHALE RUNS IN ROTARY KILN

\begin{tabular}{|c|c|c|c|c|c|c|c|c|c|c|}
\hline \multirow{2}{*}{ Run } & \multirow{2}{*}{ Shale } & \multirow{2}{*}{ Residue } & \multirow{2}{*}{ Weight } & \multicolumn{2}{|c|}{ Condensate } & \multirow{2}{*}{$\mathrm{NaOH}$} & \multirow{2}{*}{ Line } & \multirow{2}{*}{ Tot.Liq. } & \multirow{2}{*}{ Gas } & \multirow{3}{*}{$\begin{array}{l}\text { Gas as } \\
\text { of of } \\
\text { Gas }+ \\
\text { Liquid }\end{array}$} \\
\hline & & & & Bottlo & Mist & & & & & \\
\hline & \multicolumn{4}{|c|}{$1<-$} & \multicolumn{5}{|c|}{ Orams } & \\
\hline Occidental 2 & 1000.35 & 887.71 & 112.64 & 55.47 & 17.21 & 20.61 & 4.28 & 97.57 & 15.07 & 13.4 \\
\hline Occidental 3 & 1034.78 & 920.20 & 114.58 & 45.64 & 20.22 & 21.24 & 7.72 & 94.82 & 19.76 & 17.2 \\
\hline Occidental 4 & 973.17 & 863.16 & 110.01 & 50.53 & 13.81 & 22.78 & 9.86 & 96.98 & 13.03 & 11.8 \\
\hline Parachute 1 & 965.16 & 780.20 & 184.96 & 101.74 & 8.22 & 23.16 & 2.70 & 135.82 & 49.14 & 26.6 \\
\hline Parachute 2 & 1009.88 & 822.20 & 187.68 & 109.03 & 7.38 & $23^{*}$ & 4.95 & 144 & $43^{*}$ & $23 *$ \\
\hline Tipton 1 & 972.17 & 815.63 & 156.54 & 99.96 & 9.30 & 17.45 & 6.42 & 133.13 & 23.41 & 15.0 \\
\hline Tipton 2 & 959.04 & 805.97 & 153.07 & 98" & 11.86 & 18.70 & 6.20 & $135^{*}$ & $18 *$ & $12^{*}$ \\
\hline Tipton 3 & 916.24 & 764.47 & 151.77 & 97.51 & 9.84 & 14.13 & 6.10 & 127.58 & 24.19 & 15.9 \\
\hline Kentucky 1 & 1090.91 & 966.08 & 124.83 & 62.98 & 14.00 & 20.60 & 10.20 & 107.78 & 17.05 & 13.7 \\
\hline Kentucky 2 & 1013.66 & 888.11 & 125.55 & 67.85 & 12.30 & 18.58 & 4.80 & 103.53 & 22.02 & 17.5 \\
\hline Indiana 1 & 982.53 & 854.61 & 127.92 & 72.31 & 11.40 & 17.96 & 4.62 & 106.29 & 21.63 & 16.9 \\
\hline Indiana 2 & 990.04 & 867.30 & 122.74 & 75.59 & 12.37 & 10.04 & 4.86 & 102.86 & 19.88 & 16.2 \\
\hline $\begin{array}{c}\text { Run } \\
\text { Sample }\end{array}$ & $\begin{array}{c}\text { Ore } \\
\text { Fischer } \\
\text { Assay }\end{array}$ & $\begin{array}{c}\text { Oil } \\
\text { Density }\end{array}$ & $\begin{array}{l}\text { Oil } \\
\text { Yiold } \\
\end{array}$ & $\begin{array}{l}\text { Oill } \\
\text { Yield }\end{array}$ & $\begin{array}{l}\text { Relative } \\
\text { Oll Yeldt } \\
\end{array}$ & $\begin{array}{c}\text { Oil Pour } \\
\text { Point }\end{array}$ & $\begin{array}{l}\text { Percent } \\
\text { Recucted }\end{array}$ & $\begin{array}{c}\text { Minutes } \\
\text { Above } \\
900 \mathrm{~F} \\
\end{array}$ & $\begin{array}{c}\text { Maximum } \\
\text { Tomper- } \\
\text { alure }\end{array}$ & $\begin{array}{l}\text { Plugging } \\
\text { Tendenc } \\
\end{array}$ \\
\hline & $(g p t)$ & $(\mathrm{g} / \mathrm{ml})$ & $(\mathrm{ml})$ & (spt) & ( $\%$ of FA) & $(\operatorname{deg}, F)$ & $(\%)$ & $(\min )$ & (deg. F) & (x) \\
\hline Occidental & 17.81 & 0.948 & 82 & 19.8 & 111 & 70 & 11.3 & 16 & 997 & 0 \\
\hline Occidental & 17.36 & 0.948 & 81 & $\overline{18.8}$ & 108 & 70 & 11.1 & 11 & 1009 & 0 \\
\hline Oucidental & 18.64 & 0.946 & 82 & 20.2 & 109 & 70 & 11.3 & 16 & 959 & 0 \\
\hline Parachute 1 & 28.14 & 0.924 & 125 & 31.1 & 110 & 95 & 19.2 & 16 & 1037 & 0 \\
\hline Purachute 2 & 28.25 & 0.923 & 133 & 31.6 & 112 & 95 & 18.6 & 9 & 1013 & 0 \\
\hline Tipton 1 & 20.27 & 0.964 & 84 & 20.8 & 103 & 40 & 16.1 & 10 & 956 & 0 \\
\hline Tipton 2 & 20.27 & 0.962 & 86 & 21.4 & 106 & 40 & 16.0 & 8 & 999 & 0 \\
\hline Tipton 3 & 20.30 & 0.960 & 81 & 21.2 & 105 & 40 & 16.6 & 14 & 959 & 0 \\
\hline Kentucky 1 & 13.36 & 0.998 & 69 & 15.2 & 114 & OF & 11.4 & 15 & 938 & 0 \\
\hline Kentucky 2 & 13.43 & 0.998 & 66 & 15.7 & 117 & $\overline{\mathrm{OF}}$ & 12.4 & 20 & 999 & $\overline{0}$ \\
\hline Indiana I & 13.89 & 0.993 & 60 & 14.8 & 106 & $5 F$ & 13.0 & 16 & 982 & 0 \\
\hline Indiana 2 & 13.89 & 0.993 & 59 & 14.2 & 102 & $5 F$ & 12.4 & 9 & 975 & 0 \\
\hline
\end{tabular}




\section{APPENDIX C}

SUMMARY OF ANALYTICAL DATA: RAW SHALE, SPENT SHALE \& ASH 1993 OIL SHALE RUNS IN ROTARY KILN

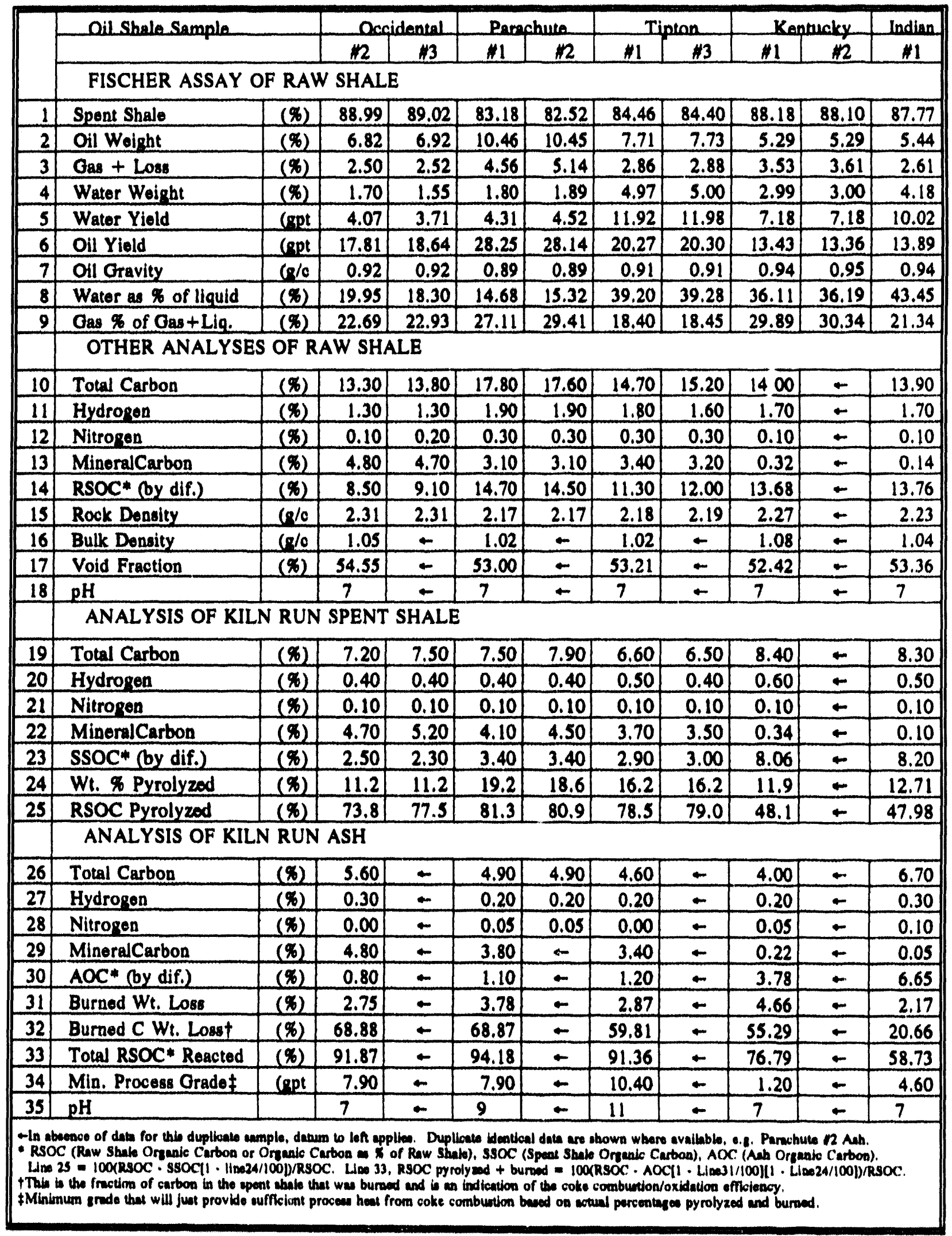




\section{APPENDIX D}

EFFECT OF PROCESSING ON PARTICLE SIZE DISTRIBUTION OIL SHALES \& RESIDUES OF RETORTED \& BURNED OIL SHALES

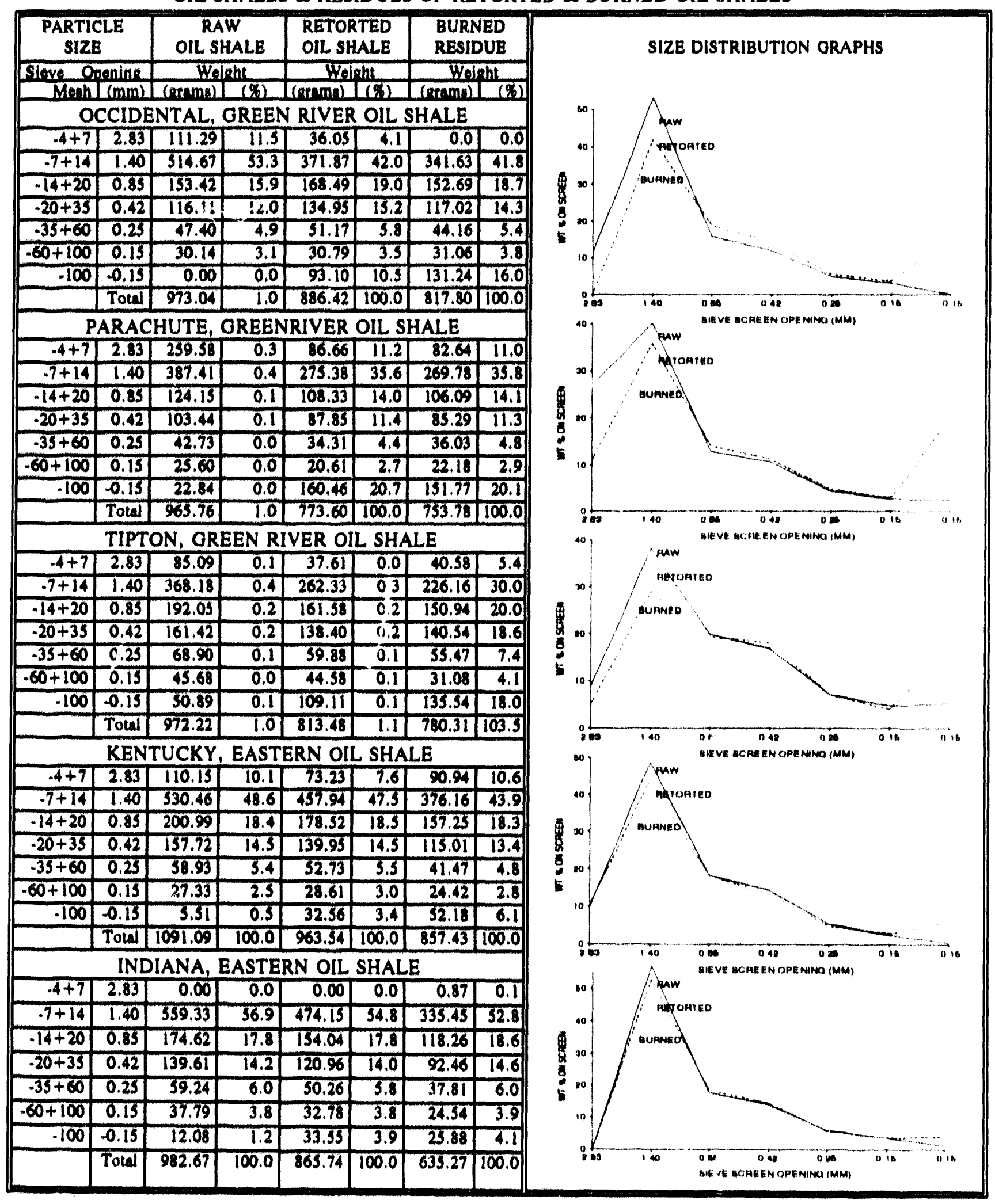




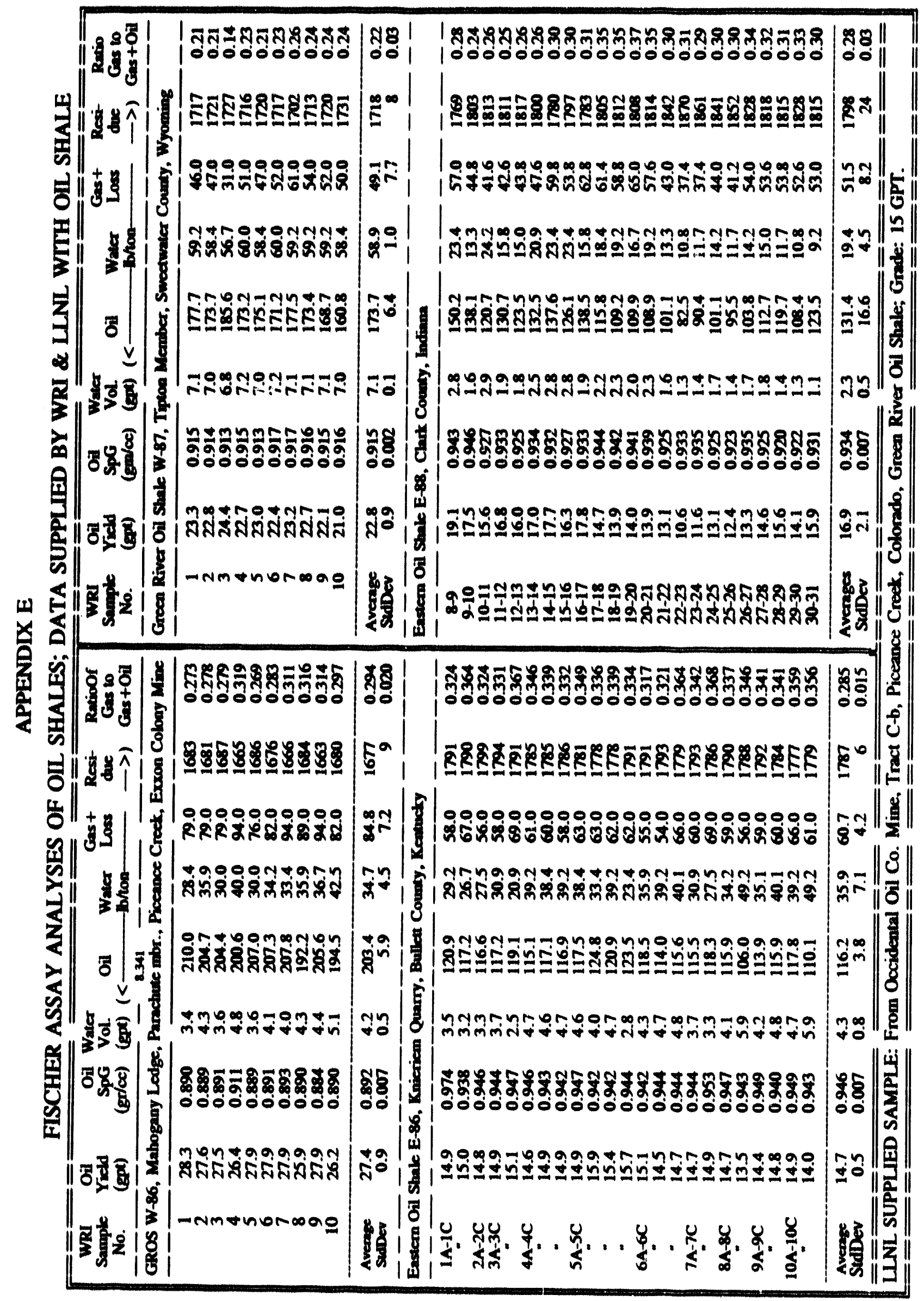




\section{APPENDIX F}

THERMOGRAVIMETRIC WEIOHT \& TEMPERATURE SUMMARY

\begin{tabular}{|c|c|c|c|c|c|c|c|c|c|c|c|c|c|c|c|}
\hline \multicolumn{2}{|c|}{$\begin{array}{l}\text { TOASamplo } \\
\text { Run No. }\end{array}$} & $\begin{array}{l}\text { Run } \\
\text { Type }\end{array}$ & $\begin{array}{l}\text { Pan } \\
\text { (mg) }\end{array}$ & $\begin{array}{c}\text { Oross } \\
W t \\
\left(m_{t}\right)\end{array}$ & $\begin{array}{l}\text { Afier } \\
\text { TOA } \\
\text { (m) }\end{array}$ & $\begin{array}{c}\text { Net } \\
\text { Wi } \\
\text { (mit) }\end{array}$ & $\begin{array}{c}\text { Find } \\
W_{t} \\
\left(m_{0}\right)\end{array}$ & $\begin{array}{l}\text { Wt } \\
\text { Loss } \\
(\mathrm{m})\end{array}$ & $\begin{array}{c}\text { Wt } \\
\text { Love } \\
(\$)\end{array}$ & $\frac{\text { Weinh }}{\text { Wower }}$ & $\begin{array}{l}\text { Lory } \\
\text { Problyab } \\
\text { (\$) }\end{array}$ & $\begin{array}{c}\text { Dirifilen } \\
\text { Ondewe } \\
\text { (s) }\end{array}$ & 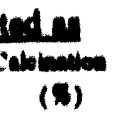 & $\underset{\text { Tan }}{\operatorname{Man}}$ & $\begin{array}{l}\text { Sxthan } \\
\text { Pnes }\end{array}$ \\
\hline 218 & $\times 5$ & Pyrk0xida & 128.8 & 239.7 & 224.9 & 110.9 & 96.1 & 14.8 & 13.32 & 0.00 & 10.0 & 1.76 & 0.0 & 324 & 7.3 \\
\hline 203 & $\mathbf{P I}$ & Pyra Oxida & 131.4 & 165.0 & 198.3 & 33.6 & 26.9 & 6.7 & 19.83 & 0.19 & 15.08 & 1.0 & 1.76 & 326 & 4.0 \\
\hline 223 & $\mathbf{P 3}$ & Pyrdoxida & 131.5 & 2105 & 195.1 & 79.0 & 63.6 & 15.4 & 19.51 & 0.7 & 14.15 & 3.32 & 1.32 & 517 & 1.7 \\
\hline 204 & $\mathbf{T 1}$ & Pyrcoxida & 128.7 & 172.2 & 164.5 & 43.5 & 35.8 & 7.7 & 17.64 & 0.42 & 14.49 & 2.23 & 0.51 & 321 & 11.0 \\
\hline 205 & $\mathbf{K 1}$ & Pyrcoxide & 128.6 & 193.7 & 179.6 & 69.1 & $\$ 1.0$ & 14.1 & 21.65 & 0.50 & 10.31 & 9.0 & 0.85 & 317 & 14.0 \\
\hline 207 & 11 & PyrdOxida & 128.6 & 194.8 & 178.5 & 66.2 & 49.9 & 16.4 & 24.70 & 0.72 & 12.60 & 10.05 & 1.32 & 525 & 10.0 \\
\hline 208 & $X I R$ & Oxidation & 128.6 & 200.0 & 197.4 & 71.3 & 68.8 & 2.5 & 3.53 & 0.60 & & 2.67 & 0.85 & 320 & 0.5 \\
\hline 209 & $\mathbf{X 2 R}$ & Oxidation & 131.4 & 2143 & 212.4 & 83.0 & 81.0 & 2.0 & 2.36 & 0.3 & & 1.84 & 0.10 & 918 & 1.0 \\
\hline 210 & PIR & Oxidation & 128.6 & 233.2 & 231.3 & 106.6 & 102.7 & 3.9 & 3.64 & 0.31 & & 3.02 & 0.31 & 510 & 3.4 \\
\hline 211 & $\mathbf{P 2 R}$ & Oxidation & 131.3 & 219.1 & 215.7 & 87.9 & 84.4 & 3.5 & 3.96 & 0.17 & & 3.41 & 0.3 & 317 & 3.4 \\
\hline 222 & $\mathbf{P B R}$ & Oxjdation & 131.3 & 282.1 & 275.7 & 150.8 & 144.4 & 6.4 & 4.22 & 0.27 & & 3.50 & 0.49 & 351 & 1.7 \\
\hline 212 & TIR & Oxidation & 128.6 & 202.0 & 199.4 & 73.3 & 70.8 & 2.5 & 3.46 & 0.2 & & 2.03 & 0.32 & 316 & 2.1 \\
\hline 214 & $\mathbf{T} \mathbf{R}$ & Oxidation & 131.4 & 200.8 & 198.3 & 69.4 & 67.0 & 2.5 & 3.57 & 0.3 & & 2.5 & 0.2 & 321 & 19 \\
\hline 215 & KIR & Oxidation & 128.8 & 210.7 & 201.4 & 82.0 & 72.6 & 9.3 & 11.38 & 0.00 & & 11.07 & 0.31 & 320 & 6.7 \\
\hline 219 & K2R & Oxidation & 131.5 & 207.9 & 197.5 & 76.4 & 66.0 & 10.4 & 13.60 & 0.00 & & 11.03 & 1.75 & 716 & I8. 3 \\
\hline 216 & IIR & Oxidation & 131.4 & 215.6 & 207.0 & 84.3 & 75.7 & 8.6 & 10.20 & 0.18 & & 9.60 & 0.42 & 320 & 7.8 \\
\hline 221 & 12R & Oxidation & 131.4 & 225.4 & 214.3 & 94.0 & 82.9 & 11.1 & 11.80 & 0.00 & & 10.4 & 1.36 & 713 & 16.0 \\
\hline 238 & IIR & StopOxidat & 128.65 & 204.12 & 195.80 & 75.5 & 67.2 & 8.3 & 11.02 & (ste & pulloger of & Xldat lor & & 303 & \\
\hline & & . & $\begin{array}{l}\text { outed to } \\
\text { Eor Pyr }\end{array}$ & olvin=0 & xidution & d at & & & $\begin{array}{l}\text { ne points } \\
\text { Eor Oxid }\end{array}$ & tion Ri & & & & & \\
\hline $\begin{array}{l}\text { Pya } \\
\text { Pyr } \\
\text { Oxi } \\
\text { Cal }\end{array}$ & $\begin{array}{l}\text { rolysis: } \\
\text { idation } \\
\text { lcinatio }\end{array}$ & & $\begin{array}{l}\text { End of } \mathrm{Hz} \\
\text { Suart of A } \\
\text { End of Py } \\
\text { oxidation }\end{array}$ & 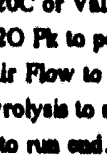 & parlad $6 \mathrm{~m}$ & new & $\begin{array}{l}\text { P. nober } \\
\text { of } \\
\text { ind }\end{array}$ & sooc. & (Not efplic & Do & I of $\mathrm{mm}$. & $120 \mathrm{C}$. & אח & $300 \mathrm{c}$. & \\
\hline
\end{tabular}

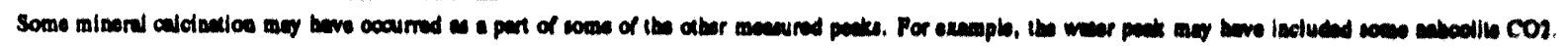

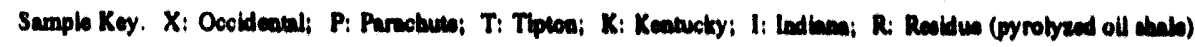




\section{APPENDIX G}

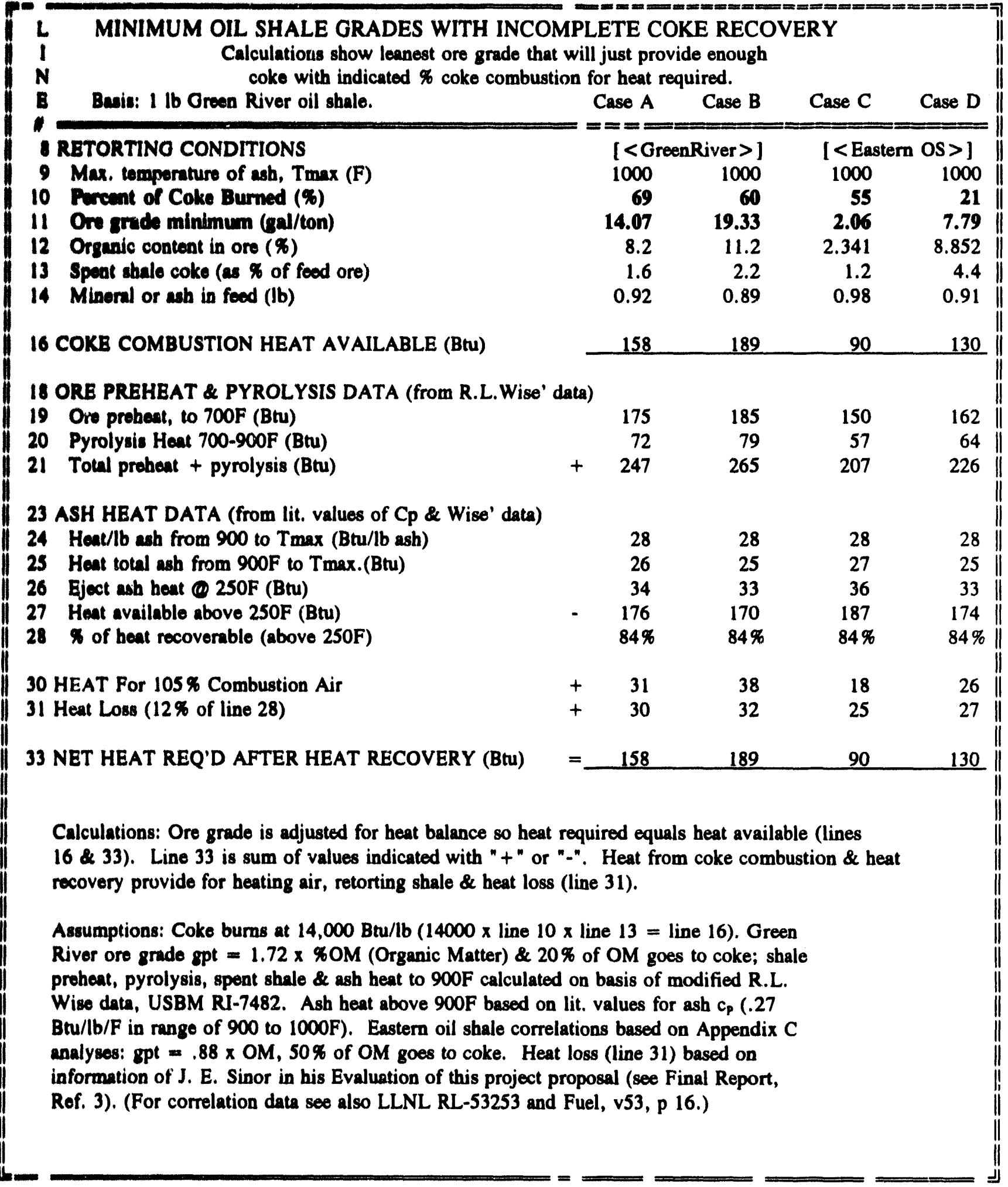



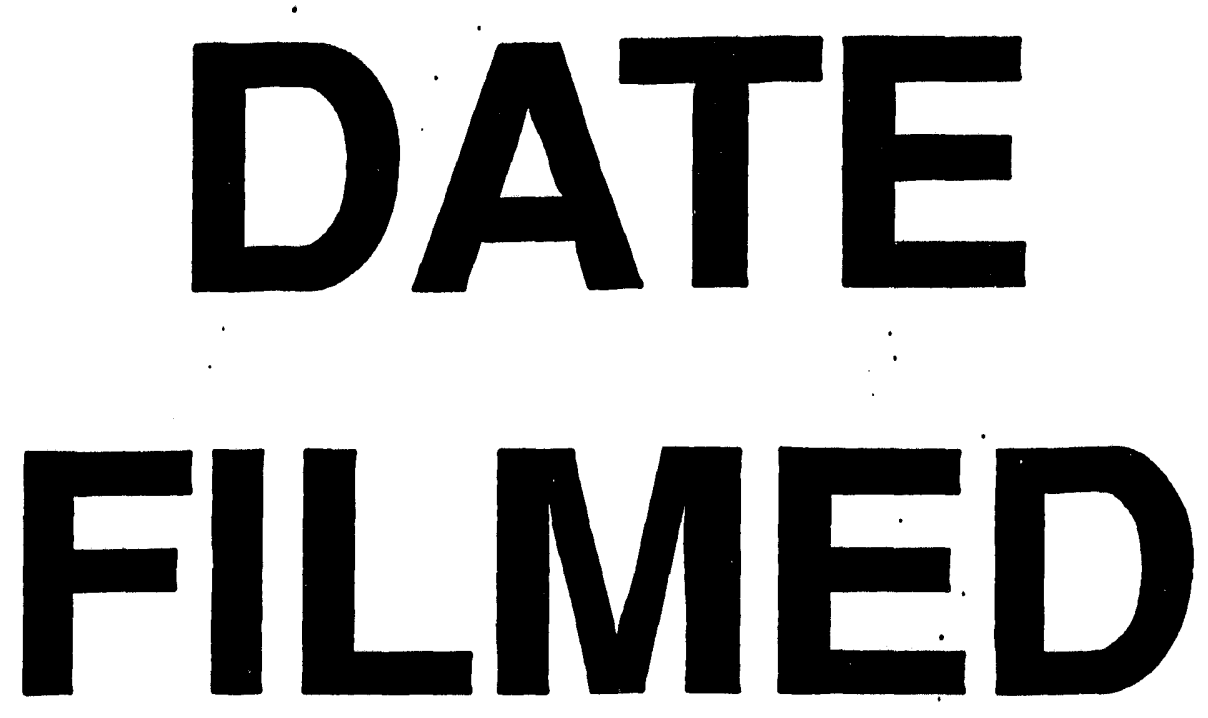

$10 / 19 / 93$
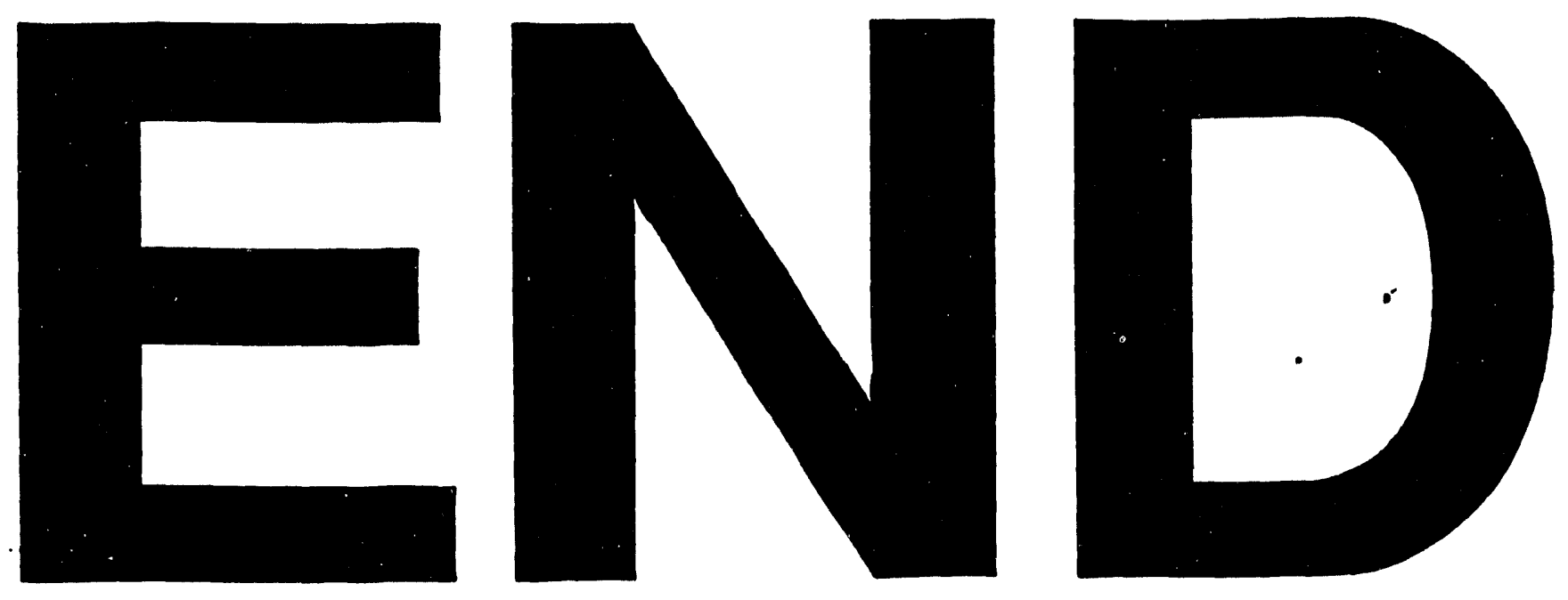
